\title{
Root Proteomic Analysis of Two Grapevine Rootstock Genotypes Showing Different Susceptibility to Salt Stress
}

\author{
Bhakti Prinsi $₫$, Osvaldo Failla $₫$, Attilio Scienza and Luca Espen *® \\ Department of Agricultural and Environmental Sciences-Production, Landscape, Agroenergy (DiSAA), \\ Università degli Studi di Milano, Via Celoria 2, 20133 Milano, Italy; bhakti.prinsi@unimi.it (B.P.); \\ osvaldo.failla@unimi.it (O.F.); attilioscienza@virgilio.it (A.S.) \\ * Correspondence: luca.espen@unimi.it; Tel.: +39-02-503-16610
}

Received: 21 December 2019; Accepted: 4 February 2020; Published: 6 February 2020

\begin{abstract}
Salinity represents a very limiting factor that affects the fertility of agricultural soils. Although grapevine is moderately susceptible to salinity, both natural causes and agricultural practices could worsen the impact of this abiotic stress. A promising possibility to reduce this problem in vineyards is the use of appropriate graft combinations. The responses of grapevine rootstocks to this abiotic stress at the root level still remain poorly investigated. In order to obtain further information on the multifaceted responses induced by salt stress at the biochemical level, in the present work we analyzed the changes that occurred under control and salt conditions in the root proteomes of two grapevine rootstock genotypes, M4 and 101.14. Moreover, we compared the results considering that M4 and 101.14 were previously described to have lower and higher susceptibility to salt stress, respectively. This study highlighted the greater capability of M4 to maintain and adapt energy metabolism (i.e., synthesis of ATP and $\mathrm{NAD}(\mathrm{P}) \mathrm{H})$ and to sustain the activation of salt-protective mechanisms (i.e., Na sequestration into the vacuole and synthesis of osmoprotectant compounds). Comparitively, in 101.14 the energy metabolism was deeply affected and there was an evident induction of the enzymatic antioxidant system that occurred, pointing to a metabolic scenario typical of a suffering tissue. Overall, this study describes for the first time in grapevine roots some of the more crucial events that characterize positive (M4) or negative (101.14) responses evoked by salt stress conditions.
\end{abstract}

Keywords: NaCl; Vitis; LC-ESI-MS/MS; carbon and energy metabolism; oxidative stress

\section{Introduction}

It is estimated that about one fifth of the world's cultivated soils is negatively affected by salinity. In addition to natural causes, land clearing and irrigation are among the main causes that are increasing this phenomenon [1]. Soil is classified as saline when it presents an electrical conductivity of more than $4 \mathrm{dS} / \mathrm{m}$, corresponding to about $40 \mathrm{mM} \mathrm{NaCl}$, a concentration that affects the productivity of most crops [2].

Salt stress is composed of osmotic and ionic components that characterize the two phases of the stress [2]. The first phase is mainly due to the increase of the osmotic pressure component of the soil solution and, likewise in drought conditions, determines a reduction of water availability, while the second phase depends on toxic effects consequent to the onset in plant cells of high concentrations of $\mathrm{Na}^{+}$and/or $\mathrm{Cl}^{-}$. In these different phases, the transport activities at the membrane level play a crucial role, being involved in root ion uptake, cellular compartmentation (i.e., transport into the vacuole) and movement to the shoot, that mainly depends on transport from the symplast to the xylem 
apoplast [1-3]. According to an alteration in water balance, plants reduce transpiration, thus affecting many biological processes, like growth, photosynthesis and ion movement among tissues [3]. Moreover, the increases in $\mathrm{Na}^{+}$and/or $\mathrm{Cl}^{-}$dramatically affect the homeostasis of other mineral nutrients and metabolic functionality, as well as inducing the formation of reactive oxygen species (ROS) [1-4]. In this context, stress sensing and signaling components also play a very important role in the plant responses to salinity [5].

Although in many cases the toxic action of $\mathrm{NaCl}$ is linked to the accumulation of exceedingly high concentrations of $\mathrm{Na}^{+}$, in woody perennial species, like grapevine, the effects of this abiotic stress are mainly associated with an accumulation of $\mathrm{Cl}^{-}$in the leaves [6]. A promising possibility to reduce the impact of increasing soil salt concentrations in vineyards is the use of appropriate graft combinations that exploit the genetic characteristics of the rootstocks (interspecific hybrids of different Vitis species, such as $V$. berlandieri, $V$. riparia and $V$. rupestris) concerning the capability to exclude the salt present in the soil and/or to reduce salt translocation to the shoot [7-12]. In this view, many studies focalized their attention on the transport activities at the root level as well as on the physiological, biochemical and molecular responses occurring in the shoot organs (i.e., leaves and fruits) in different grapevine graft combinations exposed to salt stress. However, the responses at the root level still remain poorly investigated $[7,10,13-16]$.

In previous work, we compared the responses to increasing salt concentrations in soil solution of two rootstocks, i.e., M4 [( $V$. vinifera $\times V$. berlandieri $) \times V$. berlandieri $\mathrm{cv}$. Resseguier no. 1] and 101.14 (V. riparia $\times$ V. rupestris) [17]; the study, conducted by applying gradual salt stress and following the responses for 21 days in order to analyze mainly the toxicity of the ion component [18], highlighted a lower and a greater susceptibility to salt stress of M4 and 101.14, respectively [17].

In order to obtain further information on the multifaceted responses at the biochemical levels that occur under salt stress in the roots (i.e., rootstock), in the present work we adopted the same experimental design to compare root proteomes of M4 and 101.14 genotypes in control and salt stress conditions, at the final time previously defined (i.e., 21 days of exposure to $\mathrm{NaCl}$ ).

\section{Results and Discussion}

As previously reported [17], the gradual exposure to $\mathrm{NaCl}$ (i.e., addition of $5 \mathrm{mmol} \mathrm{NaCl}$ daily for 21 days) induced in both the 101.14 and M4 rootstock genotypes a progressive reduction in stomatal conductance, photosynthetic activity and shoot growth, together with a decrease in the leaf water potential and a concomitant increase in osmolytes. Nevertheless, this previous study revealed that the negative effects induced by salt conditions were of a lesser extent in M4 than in 101.14, as highlighted by the lower inhibition of the photosynthetic performance and the higher accumulation of osmolytes. Moreover, M4 showed a greater ability to counteract the toxic action of $\mathrm{Na}^{+}$in the leaves maintaining an adequate level of $\mathrm{K}^{+}$. Finally, a greater capability of $\mathrm{M} 4$ to preserve integrity and therefore functionality of the roots was observed [17]. Starting from this information and using the same experimental design, we focalized the present study on the longest duration of salt exposure.

First of all, the comparison of the morphology of the whole root organs highlighted that the salt exposure reduced the root volume and the number of young roots in 101.14, whilst these inhibitory effects appeared less evident in M4 (Figure S1, Supplementary Materials 1), confirming different responses in the two genotypes. To gain new knowledge at a biochemical level, we analyzed the accumulation of $\mathrm{Na}^{+}$and $\mathrm{Cl}^{-}$in the roots as well as the changes occurring in the root proteomes.

\subsection{Accumulation of $\mathrm{Na}^{+}$and $\mathrm{Cl}^{-}$in the Roots}

The concentrations of $\mathrm{Na}^{+}$and $\mathrm{Cl}^{-}$significantly increased in both genotypes treated with $\mathrm{NaCl}$ for 21 days (Figure 1). The accumulation of $\mathrm{Na}^{+}$was higher than that of $\mathrm{Cl}^{-}$, suggesting that the toxic effect occurring at this time could be ascribed mainly to the accumulation of this cation. Despite the greater ability to respond to salt stress [17], the levels of $\mathrm{Na}^{+}$were higher in $\mathrm{M} 4$ than in 101.14, supporting the 
idea of a possible difference between the two genotypes in the capability to compartmentalize $\mathrm{Na}^{+}$in the vacuole.

The sequestration of $\mathrm{Na}^{+}$into the vacuole represents an important strategy in the salt stress tolerance mechanism, because it participates in the maintenance of an adequate cytoplasmic $\mathrm{K}^{+} / \mathrm{Na}^{+}$ ratio [19]. Interferences of $\mathrm{Na}^{+}$with $\mathrm{K}^{+}$in the cytoplasm, in fact, can deeply affect the overall metabolic processes [2]. The tonoplast-localized $\mathrm{Na}^{+} / \mathrm{H}^{+}$exchanger 1 (NHX1) plays a pivotal role in the vacuolar sequestration of $\mathrm{Na}^{+}[5,19]$. Its activity can be energized by the vacuolar $\mathrm{H}^{+}$-ATPase (V-ATPase) and/or the $\mathrm{H}^{+}$-PPase (V-PPase) $[5,20,21]$.

In order to investigate the possible differences in the vacuolar $\mathrm{Na}^{+}$compartmentalization capability between the two genotypes, we conducted Western blot (WB) analyses to evaluate the protein abundance of NHX1, V-PPase and V-ATPase. For this last protein, the analysis was performed with an antibody produced against a conserved peptide of subunit E (see Materials and Methods for details). The transcription of this subunit is induced in salt stress conditions [22,23]. This result was confirmed at the protein level together with evidence sustaining a possible role of subunit $\mathrm{E}$ in the modulation of V-ATPase activity [23].

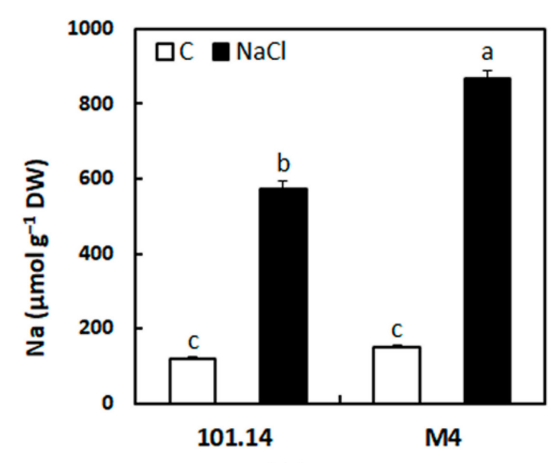

(A)

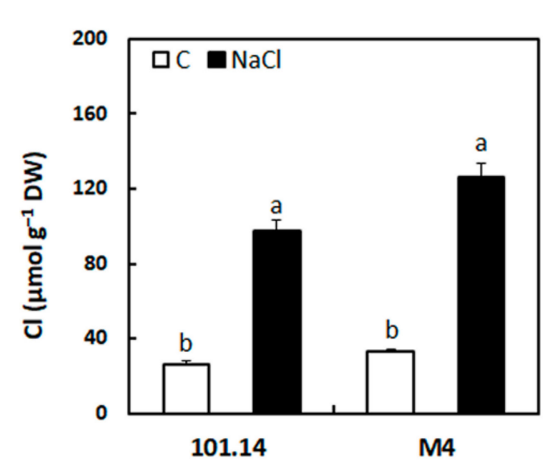

(B)

Figure 1. Levels of $\mathrm{Na}^{+}(\mathbf{A})$ and $\mathrm{Cl}^{-}(\mathbf{B})$ in roots of $\mathrm{M} 4$ and 101.14 grapevine rootstocks grown for 21 days in control $(\square)$ or salt stress ( $\square$ ) conditions. The values are the means \pm Standard Error (SE) of three biological replicates $(n=3)$. The statistical significance was assessed by analysis of variance (ANOVA) test $(p<0.05$, Tukey post hoc method).

In both genotypes, WB analyses did not reveal significant changes in protein abundance of the NHX1 and V-PPase (Figure 2A,B), whilst some differences occurred in the protein quantity of V-ATPase. Two distinct bands related to the subunit $\mathrm{E}$ of V-ATPase were visualized. This result was consistent with the presence of two protein isoforms, accordingly to the known sequences of Vitis vinifera deposited in the NCBI database. While the density of the band with a deduced molecular weight (MW) of $28 \mathrm{kDa}$ did not show significant differences in the two genotypes, the band of $30 \mathrm{kDa}$ decreased under the salt condition in 101.14 and remained unchanged in M4. In this genotype the abundances of this isoform were significantly higher than in 101.14 under both the control and the salt conditions (Figure 2C).

Taken together, these results highlighted that 101.14 and M4 had a similar capacity to transport $\mathrm{Na}^{+}$into the vacuole in the control condition and that this activity was not affected by the salt treatment. Differently, the two genotypes could have a different capability of sustaining the proton gradient necessary to drive the sequestration of $\mathrm{Na}^{+}$into the vacuole. In other words, the comparison between the two genotypes supports the idea that 101.14 could have a constitutively lower capability than M4 to pump $\mathrm{H}^{+}$into the vacuole, that is further reduced under salt stress conditions. This aspect could be related to the previous observation that M4 showed a greater capability to cope with an adverse condition represented by salt stress [17]. In this view, the greater amounts of $\mathrm{Na}^{+}$absorbed from the soil by M4 may be transported more efficiently into the vacuolar compartment (Figures 1A and 2C).

Further studies may clarify the possible role of the $30 \mathrm{kDa}$ isoform, that specifically responds to $\mathrm{NaCl}$, in the modulation of V-ATPase activity [22,23]. 


\subsection{Proteomic Analyses}

The proteomic study was performed using the GeLC-MS/MS (gel liquid chromatography- tandem mass spectrometry) approach [24]. In detail, we combined the protein extraction method previously optimized for the root proteomes of grapevine plants grown in the soil [25] with an analytical streamlined procedure recently proposed [26], based on partial 1D SDS-PAGE purification and in gel-digestion procedure. The technical parameters related to protein identification and quantitation were very similar for the two genotypes and highlighted the good reliability of the adopted protocol (Table 1). Further information about the results is reported in Tables S1 and S2 (Supplementary Materials 1).

A

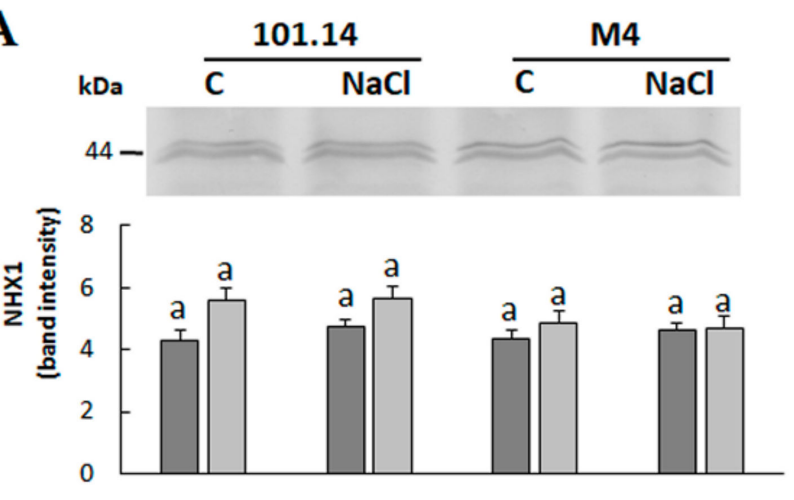

B
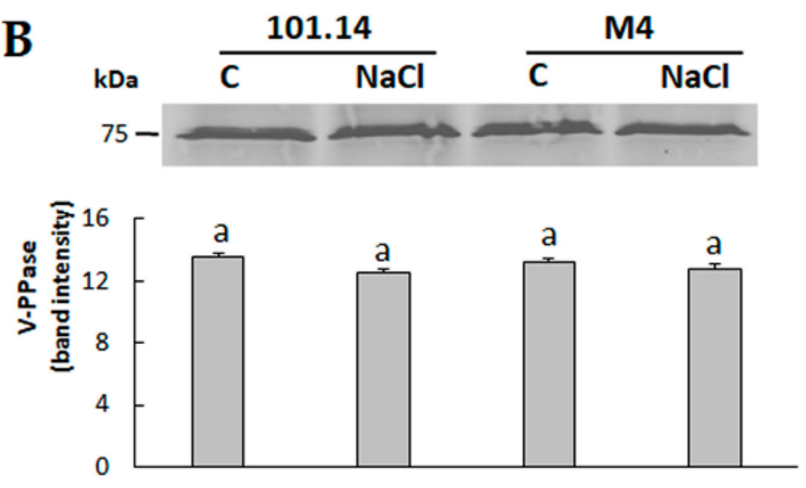

C
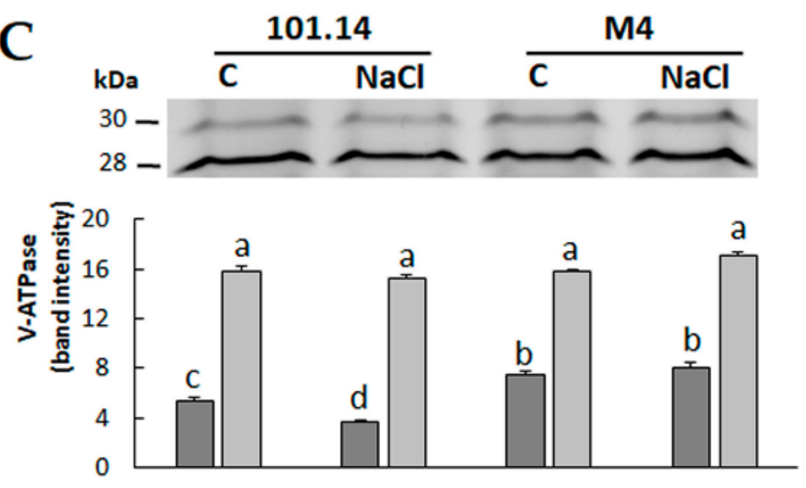

Figure 2. Western blot (WB) analyses of the NHX1 (A), V-PPase (B) and subunit E of V-ATPase (C) extracted from roots of 101.14 and M4 grapevine rootstocks grown for 21 days in control (C) or salt stress $(\mathrm{NaCl})$ conditions. When two bands were detected, dark-grey bars refer to the band with higher MW, while light-grey bars to the band with lower MW. The intensity of bands described by the histograms was quantified by densitometric analysis with ImageJ. The values are the means \pm Standard Error (SE) of three independent WB analyses $(n=3)$. The statistical significance was assessed by analysis of variance (ANOVA) test $(p<0.05$, Tukey post hoc method). 
Proteomic analysis allowed the identification and quantification of a total of 280 and 271 proteins for the 101.14 and M4 genotypes, respectively. Among these, 31\% and 34\% changed in abundance under salt stress conditions in 101.14 and M4 genotypes, respectively. In 101.14, 39 proteins increased/appeared, and 48 proteins decreased/disappeared, while in M4, 40 proteins increased/appeared and 50 proteins decreased/disappeared (Tables S1 and S2). The proteins were classified from the functional point of view according to the bin hierarchical tree developed by MapMan ontology [27].

Table 1. Evaluation of the comparative proteomic analyses in roots of 101.14 and M4 rootstock genotypes.

\begin{tabular}{ccc}
\hline Parameter & $\mathbf{1 0 1 . 1 4}$ & M4 \\
\hline n. of peptides per genotype & 15,105 & 15,131 \\
Average of unique peptide per protein $( \pm \mathrm{SE})$ & $5.0 \pm 0.2$ & $5.2 \pm 0.2$ \\
Average protein intensity & $1.43 \pm 0.039\left(\times 10^{6}\right)$ & $1.72 \pm 0.049\left(\times 10^{6}\right)$ \\
Dynamic range of protein intensity & $4.2 \times 10^{3}-2.3 \times 10^{7}$ & $7.7 \times 10^{3}-2.5 \times 10^{7}$ \\
Average protein score (Spectrum Mill) & $78.4 \pm 3.7$ & $79.7 \pm 3.9$ \\
Average amino acid coverage $\%( \pm \mathrm{SE})$ & $17.4 \pm 0.7$ & $17.4 \pm 0.7$ \\
n. of identified proteins (i.e. protein groups) & 280 & 271 \\
$n$. of differentially accumulated proteins $(\%)$ & $87(31 \%)$ & $90(34 \%)$ \\
\hline
\end{tabular}

\subsubsection{Functional Distribution of the Identified Proteins}

The functional distribution of the identified proteins is summarized in Figure S2 (Supplementary Materials 1). In the controls, the functional distribution was very similar in the two genotypes (Figure S2A,B). In this experimental condition the most represented categories were carbon and energy metabolism, protein and miscellaneous enzyme family. Salt exposure induced evident changes in all the functional categories, some of which were different in the two genotypes. Among these, carbon and energy metabolism, protein and lipid metabolism and miscellaneous enzyme families showed the greatest changes (Figure S2C,F). This result was quite similar to those found in studies concerning root proteomes of plants subjected to salt stress, even if a few differences were apparent, perhaps attributable to the experimental conditions or to peculiar responses of different species [28,29]. Among the functional classes with the higher number of proteins that appeared/increased under salt stress there were carbon and energy metabolism, the miscellaneous enzyme families and redox categories for 101.14 and carbon and energy metabolism, protein, and cell/signaling/ development categories for M4 (Figure S2C,D). Finally, in both genotypes an evident decrease/disappearance of proteins belonging to the categories of carbon and energy metabolism, lipid metabolism, and miscellaneous enzyme family was observed (Figure S2E,F). Taken together, these results showed that in optimal growth conditions the same activities were operating in roots of 101.14 and $\mathrm{M} 4$, whilst the addition of $\mathrm{NaCl}$ induced deep changes in the metabolism, some of which were different in the two genotypes.

\subsubsection{Metabolic Pathways Affected by Salt Stress}

Datasets containing all the identified proteins were displayed in a MapMan metabolism overview map (Figure 3) and in a MapMan map summarizing pathways known to be involved in stress responses (Figure 4). Tables 2 and 3 show the proteins that significantly changed under salt stress in 101.14 and M4, respectively. According to a different capability to respond to salt stress, the analysis of the proteomic results highlighted many differences between the two genotypes.

Proteomic Changes Involved in Carbon and Energy Metabolism

The proteomic results revealed that many pathways involved in carbon and energy metabolism, like glycolysis, TCA cycle, ATP synthesis and oxidative pentose phosphate pathway (OPP), were affected by salt treatment in both genotypes, but in very different ways (Figure 3, Tables 2 and 3).

In 101.14 a few enzymes of glycolysis and TCA cycle, such as fructose-bisphosphate aldolase (\#24), glyceraldehyde-3-phosphate dehydrogenase (\#61), and the dihydrolipoamide acetyltransferase 
component of pyruvate dehydrogenase complex (\#120) were negatively affected by salt exposure, whilst pyruvate kinase (\#58) and the E1 component subunit $\beta$ of mitochondrial pyruvate dehydrogenase (\#185) increased under stress conditions (Table 2).

In M4, a greater number of enzymes involved in energy metabolism changed in abundance under the salt stress condition (Table 3). Glyceraldehyde-3-phosphate dehydrogenase (\#42), fructose-bisphosphate aldolase (\#45), and fructokinase (\#13) decreased, whilst others, like cytoplasmic phosphoglucomutase (\#64), pyruvate kinase (\#97), and three subunits of mitochondrial succinate dehydrogenase (\#227, \#130 and \#172), increased. Only in M4, an increase of the subunit $\mathrm{O}$ of mitochondrial ATP synthase took place (\#133). Moreover, in this genotype, the $\alpha$-subunit and $\beta$-subunit of pyrophosphate-fructose 6-phosphate 1-phosphotransferase increased and decreased, respectively (\#91 and \#100). This latter result could be due to a change in the possible forms described for this enzyme, composed by $\beta$-doublet $\beta$-single and $\alpha+\beta$ subunits, respectively [30,31]. Further work is requested to verify if the different ratio between the two subunits observed in the two experimental conditions could be a specific response to modulate the activity of this enzyme also in non-photosynthetic tissues.

Taken together, the proteomic analyses highlighted that salt stress deeply influenced the main pathways involved in the biosynthesis of ATP, and this occurred in a manner similar to that described in roots of other species [28-32]. At the same time, the comparison between the two genotypes highlighted the greater capability of M4 to sustain the request of metabolic energy necessary to counteract the toxic effects of $\mathrm{Na}^{+}$and/or $\mathrm{Cl}^{-}$, a crucial point in coping with a high salt concentration [33]. Although a few glycolytic enzymes diminished in a similar way in both genotypes, a few enzymes crucial in the TCA cycle and ATP synthesis increased only in M4. In this context, we also observed that only in 101.14 exposed to $\mathrm{NaCl}$ the abundance of two enzymes involved in the anaerobic metabolism for ATP production, i.e., pyruvate decarboxylase (\#86) and alcohol dehydrogenase (\#64), increased. At the same time, under salt stress, an evident decrease of pyruvate decarboxylase 1 occurred in M4 (\#265). The results appear to show that, in 101.14, as reported for other species [34], salt stress can induce the activation of the fermentation pathway as a response to low ATP levels.

The reduction in the energetic metabolism may also depend on factors other than those referable to direct toxic effects of $\mathrm{NaCl}$ in root cells. In this view, an important aspect to consider is that the sugar availability in the root could decrease, since photosynthesis is affected by salt stress. Previously, in the same experimental conditions, a reduction of the net $\mathrm{CO}_{2}$ assimilation by $80 \%$ in 101.14 and by $35 \%$ in M4 was measured [17]. In this context, it is interesting to stress the dramatic increase in abundance of sucrose synthase in 101.14 (\#184, + 150 folds) and its much lower increase in M4 (\#89 and $\# 152,+11$ and +3 -folds, respectively). This result fits well with a greater and lesser necessity of the two genotypes (101.14 and M4, respectively) to strengthen the import of photoassimilates in roots, in which sucrose synthase plays a pivotal role [35]. It could be observed that the toxic effects occurring in the leaf tissue evoke in roots metabolic responses that are apt at increasing sink strength. In this stress condition, the carbon skeletons imported from the phloem would be mainly used to sustain energy metabolism, rather than to synthesize starch, as suggested by the decrease in abundance of a few plastidial enzymes involved in carbohydrate metabolism. According to this observation, the effect was more evident in 101.14 than in M4 (Figure 3, Tables 2 and 3).

The multifaceted role of NADPH, involved in several biosynthetic pathways as well as in energy metabolism and in sustaining some antioxidant systems, is well known [36]. In non-photosynthetic tissues, the production of the reduced form NADPH depends on the activity of enzymes like glucose-6-phosphate dehydrogenase (G6PDH), 6-phosphogluconate dehydrogenase (6PGDH), and NADP-dependent malic enzyme (NADP-ME). In both genotypes, this latter enzyme is increased under salt stress (\#7 and \#18 in 101.14 and M4, respectively), suggesting that Vitis NADP-ME is also involved in the root responses to high $\mathrm{NaCl}$ concentration [37]. Only in $\mathrm{M} 4$ the salt stress induced an increase of G6PDH (\#259) and 6PGDH (\#31), suggesting that this genotype was able to also sustain the reduction of $\mathrm{NADP}^{+}$by enhancing the operativeness of OPP (Figure 3, Tables 2 and 3). 
At the same time, the increase in OPP could also be linked to the requirement of precursors for the synthesis of specific metabolite(s), which might contribute to counteracting the cellular effects of salt stress. Genes codifying G6PDH are classified among those that respond early to saline stress [38], being strictly involved in the response to osmotic stress [39]. In this context, it was shown that the salt stress responses could be linked to the expression of specific isoforms [40]. Under salt stress, an evident increase in the accumulation of a betaine aldehyde dehydrogenase (\#235), involved in the synthesis of glycine-betaine, occurred in M4. The osmoprotectant glycine-betaine, whose synthesis requires reducing power, plays a central role in improving salinity and drought tolerance [41]. The result obtained in our study reinforces the relationship between G6PDH and the synthesis of osmolytes and highlights a further aspect involved in the capability of M4 to respond to salt stress conditions.

Proteomic Changes Involved in Lipid Metabolism

Lipid metabolism was deeply affected by salt stress (Figure 3, Tables 2 and 3). In both genotypes, only a phospholipase D (PLD, \#100 and \#111 in 101.14 and M4, respectively) increased under the salt stress condition. This enzyme, hydrolyzing structural phospholipids, produces phosphatidic acid that plays a key role in the signaling cascades involved in the control of many physiological processes as well as in the responses to stress conditions like salinity [42,43]. Consistent with the literature, our proteomic analysis revealed that in roots of grapevine, PLDs were also involved in the perception of salt stress. In both genotypes, the same enzymes, such as biotin carboxylase 1, an enoyl-[acyl-carrier-protein] reductase [NADH], 3-hydroxyacyl-[acyl-carrier-protein] dehydratase FabZ, biotin carboxyl carrier protein of acetyl-CoA carboxylase 2, 3-oxoacyl-[acyl-carrier-protein] reductase 2, and dihydroceramide fatty acyl 2-hydroxylase FAH1 (\#41, \#70, \#182, \#211, \#105, \#173 and 65\#, 60\#, 168\#, 203\#, 88\#, \#125, in 101.14 and M4, respectively), known to be involved in the plastidic biosynthetic pathway of fatty acids $[44,45]$ were affected by salt stress. Interestingly, this response seemed more marked in 101.14 (Tables 2 and 3). Although further work is necessary to clarify this point, the observed evident reduction of lipid metabolism could be a consequence of a different use of carbon skeletons and/or cellular energy. Moreover, the capability to counteract the reduction in fatty acids biosynthesis induced by salinity could also represent in roots a crucial point in the determination of salt tolerance, considering that deficiencies in this pathway can determine premature cell death and morphological alterations [46]. 
A

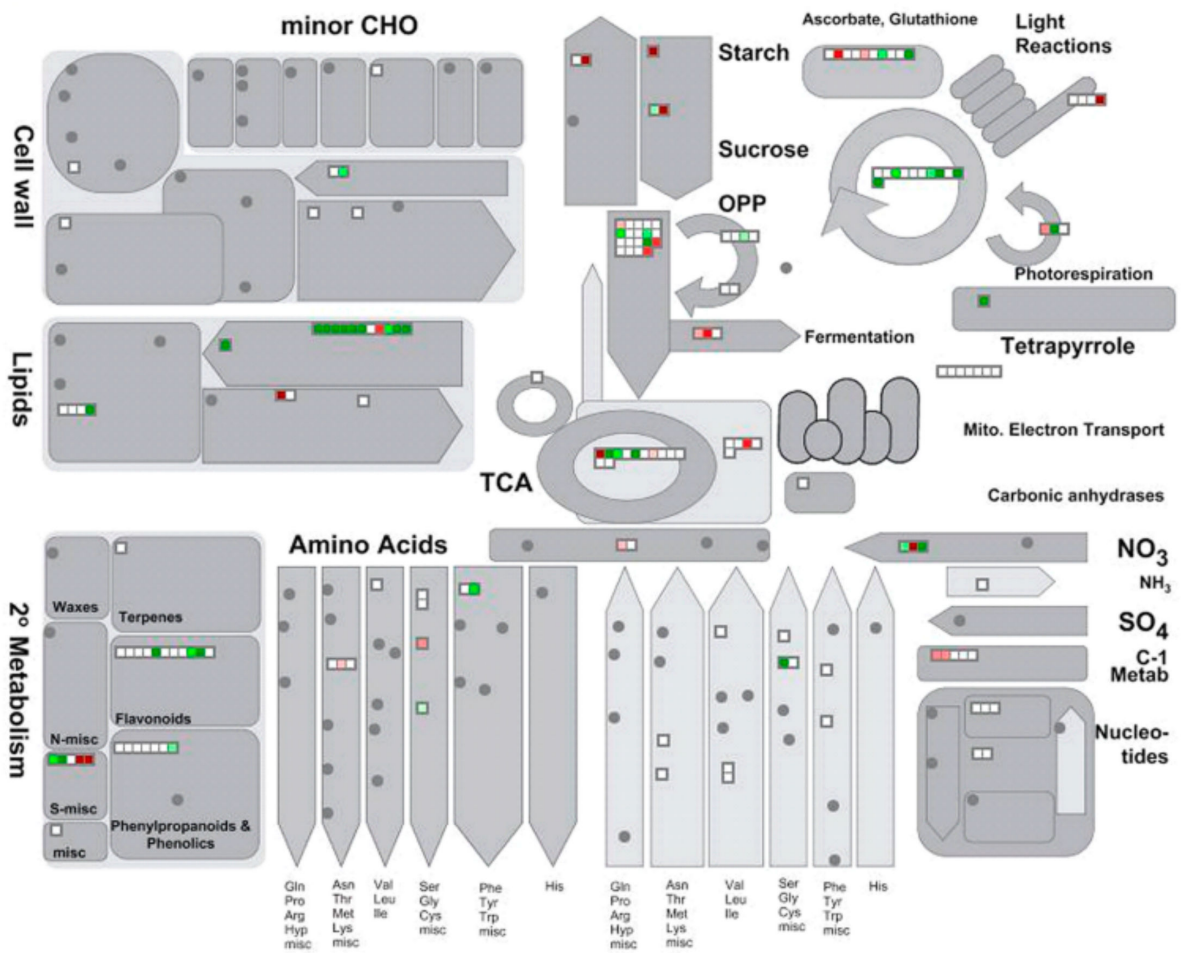

B

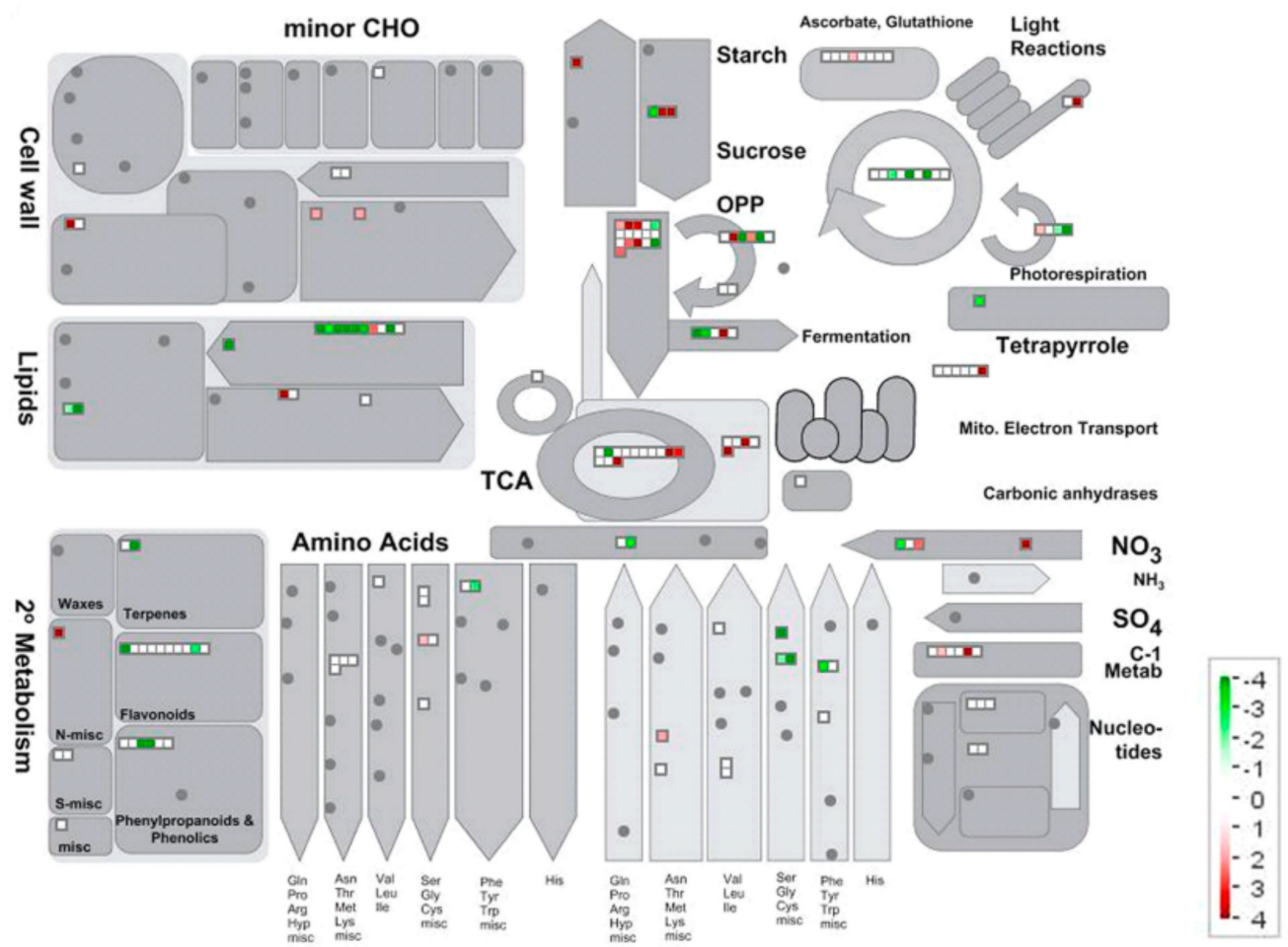

Figure 3. MapMan metabolism overview maps of the changes induced by salt stress condition. Changes in protein abundances (salt stress versus control) occurring in 101.14 (A) and M4 (B) grapevine rootstocks. Values are given in logarithmically scaled (base 1.2) signal intensities: red, increase; white, no change; green, decrease (see color scale).

Proteomic Changes Involved in N, Amino Acid and Protein Metabolism

Under salt stress a few enzymes involved in the amino acid metabolism were affected in both genotypes (Figure 3, Tables 2 and 3). The effects of salt stress conditions on amino acid metabolism are well known. This could be a direct consequence of the toxic effects of salt (particularly $\mathrm{Na}^{+}$) on 
the energy metabolism and/or on carbon skeleton availability, could depend on changes in protein turnover (i.e., different ratio between protein biosynthesis and degradation), but also could be linked to the biosynthesis of specific amino acids with an osmoprotective/antioxidant role $[41,47,48]$. A previous study, conducted in our laboratory using the same salt stress conditions adopted in the present work, showed that the total amino acid contents increased in both genotypes, whilst the total protein contents were not affected [17].

Whilst some changes in amino acid metabolism were common in the two genotypes, others were observed only in one of them. In both genotypes, a down-accumulation of a bifunctional 3-dehydroquinate dehydratase/shikimate dehydrogenase (\#191 and \#155 in 101.14 and M4, respectively) and a glyoxylate/hydroxypyruvate reductase A HPR2 (\#116 and \#139 in 101.14 and M4, respectively) occurred under salt stress. These enzymes are involved in the synthesis of aromatic amino acids and in the metabolism of amino acids belonging to the glycine group, respectively $[49,50]$. At the same time, salt stress induced in both genotypes a decrease of the cytosolic form of glutamine synthetase (\#36 and \#26 in 101.14 and M4, respectively), that could be linked to a change in plant $\mathrm{N}$ recycling [51,52]. Only in M4, nitrite reductase 1 (\#231) increased under salt stress, supporting the idea that M4 might have a greater capacity to sustain $\mathrm{N}$ assimilation under the salt stress condition adopted. At the same time, an up-accumulation of a serine hydroxymethyl-transferase (\#27), that catalyzes the conversion of glycine to serine and is reported to play an important role in leaf tissue(s) in counteracting (a)biotic stresses [53], occurred in 101.14.

Some peptidases like cysteine proteinase RD21A (\#157 and \#121 in 101.14 and M4, respectively), a carboxypeptidase (\#195 and \#185 in 101.14 and M4, respectively), procardosin-A (\#56 and \#63 in 101.14 and M4, respectively), and a peptidase_S10 domain-containing protein (\#135 and \#221 in 101.14 and M4, respectively) decreased in abundance under salt stress in both genotypes, consistent with an overall reduction in protein degradation. At the same time, only in 101.14 a $26 \mathrm{~S}$ proteasome non-ATPase regulatory subunit 2 homolog (\#149) increased and two chaperonins 60 subunit $\alpha 2$ (\#48 and \#122) decreased. Differently, in M4 a proteasome subunit $\beta$ type (\#165) decreased, whilst two elongation factors (\#30 and \#105) and a 40S ribosomal protein SA (\#80), required for the assembly and/or stabilization of the $40 \mathrm{~S}$ ribosomal subunit, increased under salt stress. Taken together, these data highlight the greater capability of M4 than 101.14 to sustain activation of protein synthesis in response to salt stress.

In both genotypes, a regulatory subunit $\mathrm{A} \beta$ isoform of serine/threonine-protein phosphatase $2 \mathrm{~A}$ (PP2A) was positively affected by the salt-stress condition (\#266 and \#260 in 101.14 and M4, respectively). PP2As are involved in reversible protein phosphorylation, a post-translational modification that plays a central role in a plethora of processes among which are environmental stress responses [54,55]. Further studies may clarify the specific role, if any, of this regulatory protein in the response to salt stress.

\section{Proteomic Changes Involved in Secondary Metabolism, Stress and Redox Metabolisms}

Salt stress negatively affected proteins classified in the secondary metabolism functional class (Figure 3, Tables 2 and 3). Among the identified proteins a flavanone 3-hydroxylase (\#93 and \#101 in 101.14 and M4, respectively) was present, that decreased in both genotypes, suggesting a reduction in the synthesis of flavonoids. The effect of salt stress on the phenolic metabolism was more evident in 101.14, where cinnamyl alcohol dehydrogenase 8 (\#161) and chalcone synthase (\#155) also decreased in abundance. Only in 101.14, salt stress induced the appearance of a bifunctional nitrilase/nitrile hydratase NIT4B-like (\#261). This enzyme, that is involved in the metabolism of cyanide (i.e., $\beta$-CAS pathway), removes $\beta$-cyanoalanine, producing $\mathrm{NH}_{4}{ }^{+}$and aspartate [56]. The relationship between cyanide metabolism and ethylene synthesis under stress conditions is described [57-59]. Although we did not observe any change in the enzymes involved in ethylene metabolism, it was realistic to hypothesize that the salt stress condition induced in 101.14 the synthesis of this hormone, consistent with 
the suffering state detectable by morphological analysis of the roots of 101.14 (Figure S1, Supplementary Materials 1).

In both genotypes, a chitinase class I basic (\#51 and \#54 in 101.14 and M4, respectively) was up-accumulated under salt stress conditions (Tables 2 and 3). A similar result was previously found in roots of the 101.14 and M4 genotypes in response to drought stress [25], thus reinforcing the idea that enhanced synthesis of this enzyme could be a response useful to counteracting the risk of infection in stress-weakened plants [60,61]. In 101.14, two germin-like proteins (\#201, \#214) showed an evident increase in abundance, while another one slightly diminished (\#128). The germin subfamily is a heterogeneous class of proteins described to be involved in the defense response to different stress conditions, such as salt stress [62,63]. Salt stress induced in M4 an increase in MLP-like protein 34 (\#110). Although further work is necessary to define the specific role, it could be stressed that the increase of MLP-like proteins have been related to a greater tolerance to stress conditions [64].

Many stresses, including salinity, are characterized by an evident increase in reactive oxygen species (ROS), that attack cell membranes and macromolecules finally affecting cell/tissue structures and metabolism functionality $[65,66]$. Although ROS play a key role in the responses to abiotic stress, excess levels of these compounds induce the typical activation of enzymatic and non-enzymatic systems to remove them [67]. In our experimental conditions, both 101.14 and M4 genotypes showed an increase in antioxidant enzymes under salt stress, even if the entity of the response was much more evident in 101.14 than in M4 (Tables 2 and 3, Figures 3 and 4). Whilst in M4 only a catalase (\#16) and a peroxidase 53 (\#263) increased, in 101.14, several antioxidant enzymes like a superoxide dismutase [Cu-Zn] (\#222), a monodehydroascorbate reductase 5, mitochondrial isoform X1 (\#59), a protein disulfide-isomerase (\#29), a catalase (\#12), a monodehydroascorbate reductase (\#44) and two peroxidases (\#153 and \#94), were up-accumulated. The greater activation of these enzymes that occurred in 101.14 suggests that this genotype must respond to a more severe oxidative stress than that occurring in M4. In other words, the lesser capability to counteract the toxic effects induced by the presence of salt concentration, suggested by several results of the present study (see above), may lead to an increase in ROS. In this view, a decrease of a GDP-mannose 3,5-epimerase (\#45), involved in ascorbate biosynthesis [68,69], did occur in 101.14, suggesting a further difficulty of this genotype in counteracting oxidative stress. Our proteomic analyses revealed the presence of the same glutathione transferase (GST) isoforms in both genotypes, all decreased under salt stress conditions (\#30, \#139 and \#134 in 101.14, \#36, \#86 and \#107 in M4). GSTs are a large group of multifunctional enzymes that show different responses to salt stress [70] and that in some cases resulted in the improvement of salt tolerance [71]. Further work is necessary to define the biochemical/physiological role(s) of the GSTs whose levels have been observed to change in the present study. 


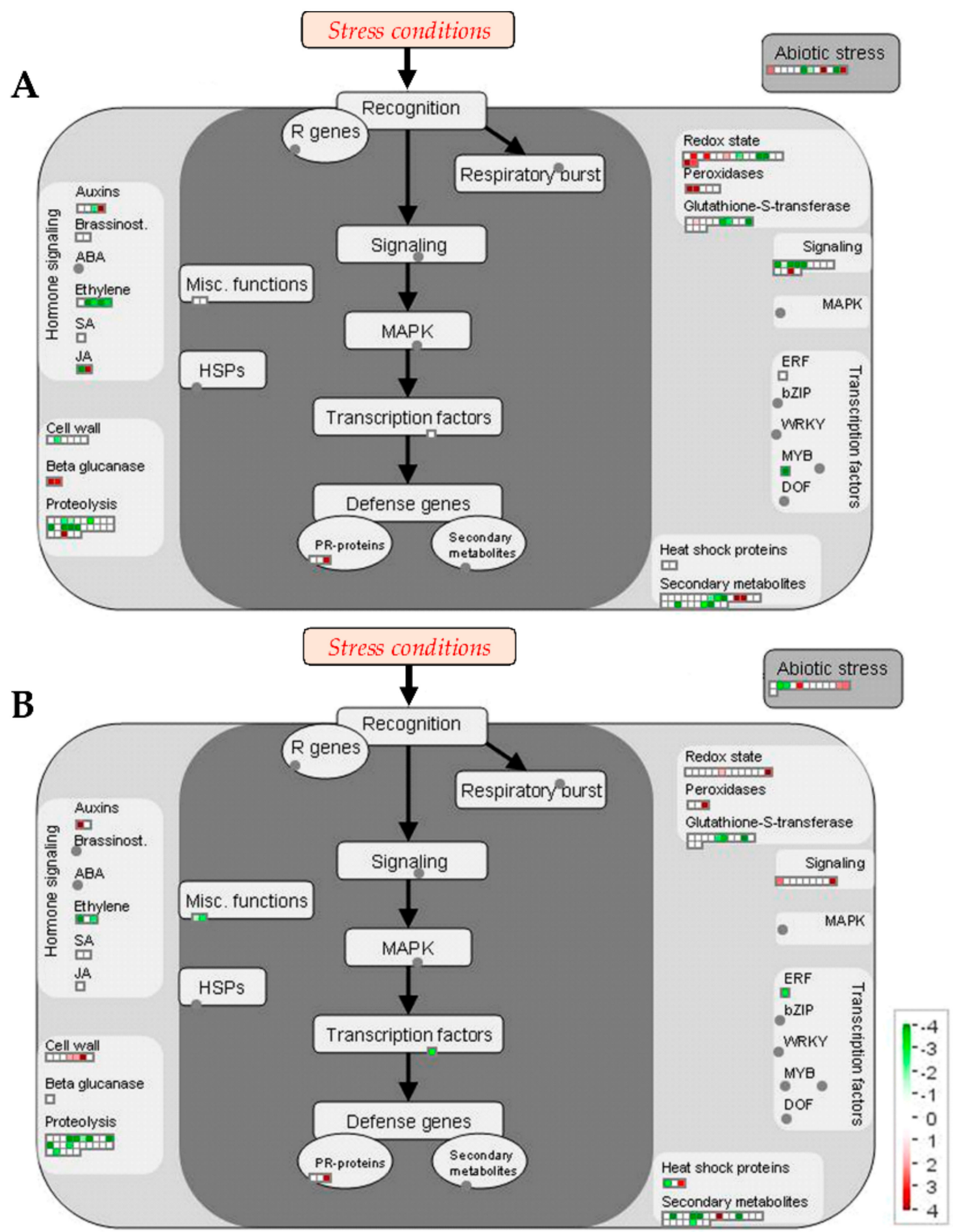

Figure 4. Changes in the MapMan overview related to stress pathways induced by salt stress. Changes in protein abundances (salt stress versus control) occurring in 101.14 (A) and M4 (B) grapevine rootstocks. Values are given in logarithmically scaled (base 1.2) signal intensities: red, increase; white, no change; green, decrease (see color scale). 
Table 2. Proteins showing significant changes in responses to salt stress in the 101.14 genotype.

\begin{tabular}{|c|c|c|c|}
\hline \# & Accession & Name (f.c.) & $\Delta \mathrm{SS} / \mathrm{C}$ \\
\hline \multicolumn{4}{|c|}{ Carbon and energy metabolism $(1-9,25)$} \\
\hline 184 & A5C6H7 & Sucrose synthase (2) & 150.46 \\
\hline 185 & F6I1P0 & Pyruvate dehydrogenase E1 component subunit beta, mitochondrial (8) & 3.49 \\
\hline 146 & F6H710 & Galactokinase, putative (3) & 2.17 \\
\hline 64 & F6I0F6 & Alcohol dehydrogenase $(5,26)$ & 1.78 \\
\hline 7 & A0A1Z2THL4 & NADP-dependent malic enzyme (8) & 1.75 \\
\hline 58 & C5DB68 & Pyruvate kinase, cytosolic isozyme $(4,11)$ & 1.70 \\
\hline 175 & F6GX20 & 4-hydroxy-4-methyl-2-oxoglutarate aldolase (25) & 1.52 \\
\hline 86 & D7TJI9 & Pyruvate decarboxylase 1 (5) & 1.42 \\
\hline 101 & A5BEM8 & Putative oxidoreductase GLYR1 (7) & -1.43 \\
\hline 24 & F6HFL6 & Fructose-bisphosphate aldolase (4) & -1.59 \\
\hline 120 & F6HFN8 & Dihydrolipoamide acetyltransferase component of pyruvate dehydrogenase complex $(8,11)$ & -1.74 \\
\hline 61 & D7T0U8 & Glyceraldehyde-3-phosphate dehydrogenase (1) & -1.77 \\
\hline 144 & F6HI27 & Pyruvate dehydrogenase E1 component subunit beta-2, chloroplastic $(8,1,11)$ & -4.93 \\
\hline 60 & F6GTG3 & Enolase 1, chloroplastic-like (4) & -6.75 \\
\hline 168 & D7SY46 & Dihydrolipoyl dehydrogenase 2 , chloroplastic $(8,11,21)$ & -26.09 \\
\hline \multicolumn{4}{|c|}{ Lipid metabolism (11) } \\
\hline 100 & $\mathrm{~F} 6 \mathrm{HXC8}$ & Phospholipase D $(11,1,27)$ & 3.90 \\
\hline 41 & F6H9P9 & Biotin carboxylase 1, chloroplastic (11) & -2.57 \\
\hline 70 & F6HLJ7 & Enoyl-[acyl-carrier-protein] reductase [NADH] 1, chloroplastic (11) & -2.13 \\
\hline 182 & D7STF0 & 3-hydroxyacyl-[acyl-carrier-protein] dehydratase FabZ (11) & -3.22 \\
\hline 211 & D7T4I1 & Biotin carboxyl carrier protein of acetyl-CoA carboxylase 2, chloroplastic (11) & -4.35 \\
\hline 105 & D7TAP7 & 3-oxoacyl-[acyl-carrier-protein] reductase 2 , chloroplastic $(11,26)$ & -12.24 \\
\hline 173 & $\mathrm{~A} 5 \mathrm{C} 5 \mathrm{~V} 3$ & Dihydroceramide fatty acyl 2-hydroxylase FAH1 (11) & -32.25 \\
\hline 188 & D7TVI4 & 3-oxoacyl-[acyl-carrier-protein] synthase I, chloroplastic (11) & d. \\
\hline \multicolumn{4}{|c|}{$N$ and amino acid metabolism $(12,13)$} \\
\hline 27 & F6GWF3 & Serine hydroxymethyltransferase $(13,1)$ & 1.49 \\
\hline 36 & P51119 & Glutamine synthetase cytosolic isozyme $2(12)$ & -1.54 \\
\hline 191 & A5ATW2 & Bifunctional 3-dehydroquinate dehydratase/shikimate dehydrogenase (13) & -1.79 \\
\hline 116 & A5CAL1 & Glyoxylate/hydroxypyruvate reductase A HPR2 $(13,1,26)$ & -2.59 \\
\hline \multicolumn{4}{|c|}{ Secondary metabolism (16) } \\
\hline 256 & F6HHQ2 & Nitrile-specifier protein $5(16)$ & New \\
\hline 261 & F6I080 & Bifunctional nitrilase/nitrile hydratase NIT4B-like $(16,26)$ & New \\
\hline 161 & D7TRU0 & Cinnamyl alcohol dehydrogenase 8 (16) & -1.50 \\
\hline 215 & D7U0Q6 & Probable plastid-lipid-associated protein 1 , chloroplastic $(16,17,26)$ & -1.78 \\
\hline 93 & A0A0M5I8D0 & Flavanone 3-hydroxylase (16) & -1.78 \\
\hline 155 & $\mathrm{O} 22519$ & Chalcone synthase (16) & -14.75 \\
\hline 250 & S5FNE7 & Protein SRG1 $(16,17)$ & d. \\
\hline \multicolumn{4}{|c|}{ Hormone metabolism (17) } \\
\hline 85 & D7TUK1 & Perakine reductase isoform X1 $(17,26)$ & 5.71 \\
\hline 207 & A3QRC1 & Allene oxide cyclase 2 , chloroplastic $(17,20)$ & -2.06 \\
\hline 224 & F6HX49 & Gibberellin 20 oxidase $1(17,16,26)$ & -2.39 \\
\hline \multicolumn{4}{|c|}{ Stress $(20)$} \\
\hline 201 & Q0MYQ7 & Germin-like protein $2(20,15,31)$ & 44.61 \\
\hline 51 & A3QRB7 & Chitinase class I basic (20) & 2.47 \\
\hline 214 & F6HZ19 & Germin-like protein subfamily 1 member $17(20,12,27,34)$ & 2.46 \\
\hline 96 & A5ASS2 & Thaumatin (20) & 1.60 \\
\hline 128 & A5BAY1 & Germin-like protein $9-2(20,15)$ & -1.42 \\
\hline 165 & D7TKM8 & Putative germin-like protein $2-1(20,12,27,30,34)$ & -2.42 \\
\hline \multicolumn{4}{|c|}{ Redox (21) } \\
\hline 222 & F6HTY5 & Superoxide dismutase $[\mathrm{Cu}-\mathrm{Zn}](21)$ & 2.11 \\
\hline 59 & A5C8L8 & Monodehydroascorbate reductase 5 , mitochondrial isoform X1 (21) & 1.84 \\
\hline 29 & E0CR49 & Protein disulfide-isomerase (21) & 1.81 \\
\hline 12 & Q8S568 & Catalase (21) & 1.69 \\
\hline 44 & A5JPK7 & Monodehydroascorbate reductase (21) & 1.43 \\
\hline 45 & F6HDW4 & GDP-mannose 3,5-epimerase $(10,21)$ & -1.61 \\
\hline
\end{tabular}


Table 2. Cont.

\begin{tabular}{|c|c|c|c|}
\hline$\#$ & Accession & Name (f.c.) & $\Delta \mathrm{SS} / \mathrm{C}$ \\
\hline \multicolumn{4}{|c|}{ Miscellaneous enzyme families (26) } \\
\hline 153 & A7NY33 & Peroxidase $4(26,16)$ & New \\
\hline 94 & F6GWS4 & Peroxidase $(26)$ & 4.88 \\
\hline 22 & Q9M563 & Beta-1,3-glucanase (26) & 1.90 \\
\hline 90 & A5AKD8 & Peptidyl-prolyl cis-trans isomerase (26) & 1.44 \\
\hline 139 & F6GT84 & Glutathione S-transferase U9 (26) & -1.97 \\
\hline 104 & D7TE48 & Soluble epoxide hydrolase (26) & -2.41 \\
\hline 134 & A5AZ36 & Glutathione S-transferase U25 (26) & -2.85 \\
\hline 249 & F6HL77 & Tropinone reductase homolog At1g07440 $(34,2)$ & -29.52 \\
\hline 190 & D7T8G2 & Purple acid phosphatase (26) & -38.33 \\
\hline 170 & F6HZD8 & Short-chain dehydrogenase reductase 3b-like (26) & d. \\
\hline \multicolumn{4}{|c|}{$D N A / R N A(27,28)$} \\
\hline 223 & A5AXT8 & Pentatricopeptide repeat-containing protein At5g66520-like $(27,26)$ & d. \\
\hline \multicolumn{4}{|c|}{ Protein (29) } \\
\hline 277 & F6H2W4 & Aspartate-tRNA ligase 2, cytoplasmic (29) & New \\
\hline 266 & D7SIX7 & Serine/threonine-prot. phosphatase 2A 65 kDa regulatory sub. A isoform (29) & 5.60 \\
\hline 149 & E0CTI4 & $26 \mathrm{~S}$ proteasome non-ATPase regulatory subunit 2 homolog (29) & 2.92 \\
\hline 56 & F6H7H1 & Procardosin-A (29) & -1.40 \\
\hline 157 & F6GZY7 & Cysteine proteinase RD21A (29) & -1.54 \\
\hline 135 & A5BIH7 & Peptidase_S10 domain-containing protein (29) & -1.82 \\
\hline 195 & F6H1D7 & Carboxypeptidase (29) & -2.08 \\
\hline 186 & D7SHN2 & Heme-binding protein 2-like $(29,19)$ & -2.63 \\
\hline 202 & D7T9L8 & Coatomer subunit delta (31) & -2.21 \\
\hline \multicolumn{4}{|c|}{ Transport (34) } \\
\hline 246 & F6H9B5 & Glucose-6-phosphate/phosphate translocator 1, chloroplastic & 4.78 \\
\hline 133 & F6HXK4 & Plasma membrane ATPase (34) & 2.32 \\
\hline 210 & F6HS56 & Potassium channel beta, putative $(34,17)$ & -1.59 \\
\hline \multicolumn{4}{|c|}{ Others $(15,18)$} \\
\hline 227 & F6H2P8 & Protein DJ-1 homolog B (18) & 6.81 \\
\hline \multicolumn{4}{|c|}{ Not assigned (35) } \\
\hline 87 & F6HHU9 & Uncharacterized protein (35) & 16.51 \\
\hline 37 & F6HUS6 & Uncharacterized protein (35) & 1.78 \\
\hline 136 & F6HJB9 & Uncharacterized protein (35) & -2.30 \\
\hline 238 & F6H0J2 & DPP6 N-terminal domain-like protein (35) & -2.53 \\
\hline 219 & A5B729 & Uncharacterized protein & d. \\
\hline
\end{tabular}

Numbers reported in brackets refer to bin code (i.e., major functional categories). \#: identification number. f.c.: bin code of functional categories. $\Delta \mathrm{SS} / \mathrm{C}$ : fold changes in salt-stressed plants compared to the control ones (up: \%(SI)WS/\%(SI)C, down: - \%(SI)C/\%(SI)WS). new: not present in the controls; d.: disappeared, not present in salt-stressed plants. 
Table 3. Proteins showing significant changes in responses to salt stress in the M4 genotype.

\begin{tabular}{|c|c|c|c|}
\hline$\#$ & Accession & Name (f.c.) & $\Delta \mathrm{SS} / \mathrm{C}$ \\
\hline \multicolumn{4}{|c|}{ Carbon and energy metabolism $(1-9,25)$} \\
\hline 89 & $\mathrm{~A} 5 \mathrm{C} 6 \mathrm{H} 7$ & Sucrose synthase (2) & 10.91 \\
\hline 235 & D7SHY3 & Betaine aldehyde dehydrogenase 1 , chloroplastic $(5,16)$ & 8.62 \\
\hline 64 & F6HFF7 & Phosphoglucomutase, cytoplasmic $1(4)$ & 3.46 \\
\hline 227 & A5BF93 & Succinate-CoA ligase [ADP-forming] subunit beta, mitochondrial (8) & 3.44 \\
\hline 152 & F6HGZ9 & Sucrose synthase (2) & 3.11 \\
\hline 133 & D7T300 & ATP synthase subunit $\mathrm{O}$, mitochondrial (9) & 3.06 \\
\hline 259 & F6HHP3 & Glucose-6-phosphate 1-dehydrogenase $(7,30)$ & 3.01 \\
\hline 130 & F6H9T6 & Succinate-semialdehyde dehydrogenase, mitochondrial (8) & 2.45 \\
\hline 18 & A0A1Z2THL4 & NADP-dependent malic enzyme (8) & 2.24 \\
\hline 187 & F6I5I7 & Methylenetetrahydrofolate reductase (25) & 2.24 \\
\hline 91 & F6I6W5 & Pyrophosphate-fructose 6-phosphate 1-phosphotransferase subunit alpha (4) & 1.97 \\
\hline 172 & D7SPF1 & Succinate dehydrogenase [ubiquinone] flavoprotein subunit, mitochondrial (8) & 1.85 \\
\hline 97 & C5DB68 & Pyruvate kinase $(4,11)$ & 1.60 \\
\hline 31 & F6HGH4 & 6-phosphogluconate dehydrogenase, decarboxylating (7) & 1.53 \\
\hline 23 & F6I0H8 & UTP-glucose-1-phosphate uridylyl transferase (4) & 1.44 \\
\hline 42 & D7T0U8 & Glyceraldehyde-3-phosphate dehydrogenase (1) & -1.56 \\
\hline 45 & F6HFL6 & Fructose-bisphosphate aldolase (4) & -1.72 \\
\hline 13 & A5B8T3 & Fructokinase (2) & -1.86 \\
\hline 72 & D7TJI9 & Pyruvate decarboxylase 1 (5) & -1.90 \\
\hline 132 & A5BEM8 & Oxidoreductase GLYR1 (7) & -2.60 \\
\hline 100 & D7TR81 & Pyrophosphate-fructose 6-phosphate 1-phosphotransferase subunit beta (4) & -2.96 \\
\hline 46 & F6I134 & Triosephosphate isomerase, chloroplastic $(1,21)$ & -3.06 \\
\hline 207 & C0KY93 & Leucoanthocyanidin dioxygenase $(1,7,13,16,17,26)$ & -3.29 \\
\hline 192 & F6HI27 & Pyruvate dehydrogenase E1 component subunit beta-2, chloroplastic $(1,8,11)$ & -3.75 \\
\hline 265 & F6GY71 & Pyruvate decarboxylase 1 (5) & -18.60 \\
\hline \multicolumn{4}{|c|}{ Cell Wall (10) } \\
\hline 233 & F6I390 & Pectinesterase (10) & 5.87 \\
\hline 57 & F6I6R4 & Beta-xylosidase/alpha-L-arabinofuranosidase 2 (10) & 1.44 \\
\hline \multicolumn{4}{|c|}{ Lipid metabolism (11) } \\
\hline 111 & F6HXC8 & Phospholipase D $(11,1)$ & 3.51 \\
\hline 73 & A5AS18 & Putative quinone reductase $(11)$ & -1.42 \\
\hline 60 & F6HLJ7 & Enoyl-[acyl-carrier-protein] reductase [NADH] 1, chloroplastic isoform X1 (11) & -1.68 \\
\hline 65 & F6H9P9 & Biotin carboxylase 1 , chloroplastic () & -1.76 \\
\hline 168 & D7STF0 & 3-hydroxyacyl-[acyl-carrier-protein] dehydratase FabZ (11) & -1.94 \\
\hline 203 & D7T4I1 & Biotin carboxyl carrier protein of acetyl-CoA carboxylase 2, chloroplastic (11) & -2.98 \\
\hline 88 & D7TAP7 & 3-oxoacyl-[acyl-carrier-protein] reductase 2 , chloroplastic $(11,26)$ & -3.19 \\
\hline 125 & $\mathrm{~A} 5 \mathrm{C} 5 \mathrm{~V} 3$ & Dihydroceramide fatty acyl 2-hydroxylase FAH1 (11) & -7.02 \\
\hline 141 & D7TVI4 & 3-oxoacyl-[acyl-carrier-protein] synthase I, chloroplastic (11) & d. \\
\hline \multicolumn{4}{|c|}{$N$ and amino acid metabolism $(12,13)$} \\
\hline 231 & F6HQA7 & Nitrite reductase $1(12)$ & 4.11 \\
\hline 25 & A5C5K3 & Adenosyl homocysteinase (13) & 1.43 \\
\hline 139 & A5CAL1 & Glyoxylate/hydroxypyruvate reductase A HPR2 $(13,1,26)$ & -1.45 \\
\hline 155 & A5ATW2 & Bifunctional 3-dehydroquinate dehydratase/shikimate dehydrogenase (13) & -1.61 \\
\hline 26 & P51119 & Glutamine synthetase cytosolic isozyme $2(12)$ & -1.72 \\
\hline 160 & D7SW04 & $\begin{array}{l}\text { Bifunctional aspartate aminotransferase and glutamate/aspartate-prephenate } \\
\text { aminotransferase isoform X2 (13) }\end{array}$ & -1.80 \\
\hline \multicolumn{4}{|c|}{ Secondary metabolism (16) } \\
\hline 101 & A0A0M5I8D0 & Flavanone 3-hydroxylase $(16,17,29)$ & -1.63 \\
\hline 50 & F6H775 & Class I-like SAM-binding methyltransferase superfamily $(16,26)$ & -4.95 \\
\hline 257 & F6GX19 & Isopentenyl-diphosphate Delta-isomerase I (16) & -6.85 \\
\hline 213 & A5BVM7 & O-methyltransferase YrrM (16) & -7.23 \\
\hline \multicolumn{4}{|c|}{ Hormone metabolism (17) } \\
\hline 241 & A5B174 & Perakine reductase (17) & 10.76 \\
\hline
\end{tabular}


Table 3. Cont.

\begin{tabular}{|c|c|c|c|}
\hline$\#$ & Accession & Name (f.c.) & $\Delta \mathrm{SS} / \mathrm{C}$ \\
\hline \multicolumn{4}{|c|}{ Stress (20) } \\
\hline 54 & A3QRB7 & Chitinase class I basic (20) & 2.16 \\
\hline 43 & D7TS57 & Chaperonin CPN60-2, mitochondrial $(20,29)$ & 1.82 \\
\hline 163 & D7TKM8 & Germin-like protein 2-1 $(12,20,27,30,34)$ & 1.59 \\
\hline 110 & D7T8R2 & MLP-like protein $34(20)$ & 1.54 \\
\hline 264 & D7TNE5 & Hypersensitive-induced response protein 1-like isoform X1 (20) & -1.64 \\
\hline 252 & A5AKX5 & SOUL heme-binding protein $(19,29)$ & -1.71 \\
\hline 71 & F6GTP0 & Heat shock protein, putative $(20,27)$ & -1.73 \\
\hline 251 & D7UE33 & PLAT domain-containing protein 3-like (20) & -1.81 \\
\hline \multicolumn{4}{|c|}{ Redox (21) } \\
\hline 16 & Q8S568 & Catalase (21) & 2.61 \\
\hline \multicolumn{4}{|c|}{ Miscellaneous enzyme families (26) } \\
\hline 263 & F6GUF3 & Peroxidase $53(26)$ & New \\
\hline 218 & F6HIC8 & Dienelactone hydrolase (26) & 1.42 \\
\hline 48 & F6I4V3 & ADP-ribosylation factor 1-like $2(26,33)$ & -1.51 \\
\hline 266 & D7TUE8 & Glycosyltransferase (26) & -1.56 \\
\hline 86 & F6GT84 & Glutathione S-transferase U9 (26) & -1.66 \\
\hline 36 & F6HR72 & Glutathione S-transferase (26) & -1.93 \\
\hline 67 & A0A024FS61 & Polyphenol_oxidase (26) & -1.90 \\
\hline 107 & A5AZ36 & Glutathione S-transferase U25 (26) & -3.16 \\
\hline 234 & D7TE48 & Soluble epoxide hydrolase (26) & -4.66 \\
\hline 167 & F6HZD8 & Short-chain dehydrogenase reductase 3b-like (26) & -10.74 \\
\hline 188 & D7T8G2 & Purple acid phosphatase (26) & -54.69 \\
\hline \multicolumn{4}{|c|}{$D N A / R N A(27,28)$} \\
\hline 225 & A5ARE0 & Glutelin type-A 1-like $(28,33)$ & 7.40 \\
\hline 28 & D7TCM7 & UPI00053F79C7 (RNA helicase) (27) & 1.48 \\
\hline 118 & A5B427 & Cyclase (28) & 1.41 \\
\hline \multicolumn{4}{|c|}{ Protein $(29)$} \\
\hline 260 & D7SIX7 & Serine/threonine-prot. phosphatase 2A $65 \mathrm{kDa}$ regulatory sub. A isoform (29) & New \\
\hline 105 & F6I455 & Probable elongation factor 1-gamma $2(29)$ & 4.34 \\
\hline 30 & F6H4T7 & Elongation factor $2(29)$ & 2.16 \\
\hline 80 & A5BUU4 & $40 S$ ribosomal protein SA (29) & 1.95 \\
\hline 134 & E0CV68 & Importin subunit beta-1 (29) & 1.52 \\
\hline 121 & F6GZY7 & Cysteine proteinase RD21A $(29,34)$ & -1.47 \\
\hline 165 & E0CR38 & Proteasome subunit beta type (29) & -1.71 \\
\hline 63 & F6H7H1 & Procardosin-A (29) & -2.12 \\
\hline 185 & F6H1D7 & Carboxypeptidase (29) & -5.53 \\
\hline 221 & A5BIH7 & Peptidase_S10 domain-containing protein (29) & -7.81 \\
\hline 197 & A5AKL4 & Cysteine protease, putative $(29,34)$ & d. \\
\hline 201 & D7TW90 & Cucumsin (29) & d. \\
\hline \multicolumn{4}{|c|}{ Cell/signaling/development $(30,31,33)$} \\
\hline 224 & D7SJV3 & Clathrin heavy chain (31) & New \\
\hline 12 & A5BTZ8 & Annexin (31) & 1.43 \\
\hline 8 & F6I0I5 & Actin-8 (31) & -1.42 \\
\hline 190 & D7T9L8 & Coatomer subunit delta (31) & -2.20 \\
\hline \multicolumn{4}{|c|}{ Transport (34) } \\
\hline 39 & F6HBF2 & ADP, ATP carrier protein, mitochondrial $(34,2)$ & 3.37 \\
\hline \multicolumn{4}{|c|}{ Not assigned (35) } \\
\hline 228 & D7T9K4 & Uncharacterized protein (35) & 3.04 \\
\hline 226 & D7SJF5 & Uncharacterized protein (35) & 1.96 \\
\hline 174 & A5B729 & Uncharacterized protein (35) & -21.21 \\
\hline
\end{tabular}

Numbers reported in brackets refer to bin code (i.e., major functional categories). \#: identification number. f.c.: bin code of functional categories. $\Delta \mathrm{SS} / \mathrm{C}$ : fold changes in salt-stressed plants compared to the control ones (up: \%(SI)WS/\%(SI)C, down: - \%(SI)C/\%(SI)WS). new: not present in the controls; d.: disappeared, not present in salt-stressed plants. 


\subsubsection{Final Considerations}

This work provides new information about the responses to salt stress of the root organ of grapevine plants. The comparative proteomic analysis between two genotypes, which were previously shown to have lower (M4) or higher (101.14) susceptibility to high $\mathrm{NaCl}$ concentrations [17], allow for the identification of a few crucial traits that seem to play a central role in the biochemical responses and/or in relieving the salt effects. The main changes occurring under salt stress in the two genotypes are summarized in Figure 5. According to studies conducted in other plant species, the capability to sequestrate $\mathrm{Na}^{+}$into the vacuole appears to play a key role in the salt response also in the roots of this woody plant. The capability to sustain the energy cost required by the salt-protective mechanisms is a very central point in the response [33,72]. In this context, the M4 genotype turned-out to better sustain the pathways involved in the synthesis of ATP and NADPH. The ability to maintain protein synthesis as well as to produce osmoprotectant compounds, such as glycine-betaine, are other traits found only in M4. On the contrary, in 101.14 a very critical situation emerged. In this more sensitive genotype, the energy metabolism was deeply affected. This deficiency could depend on several factors, like a lesser capability to sequester $\mathrm{Na}^{+}$into the vacuole, but also the higher difficulty to import sugars from the shoot into the root. In the salt stress condition, an evident induction of the enzymatic antioxidant system occurred, even if the simultaneous difficulty to adequately sustain the production of reducing power (i.e., the synthesis of NADPH and ascorbate) seemed to undermine the capability of 101.14 root tissues to operate against the salt stress condition.

Overall, this study provides new knowledge about biochemical responses occurring in grapevine rootstocks exposed to salt stress conditions. This information may be useful in future investigations needed to verify the performance of these genotypes in different graft combinations.
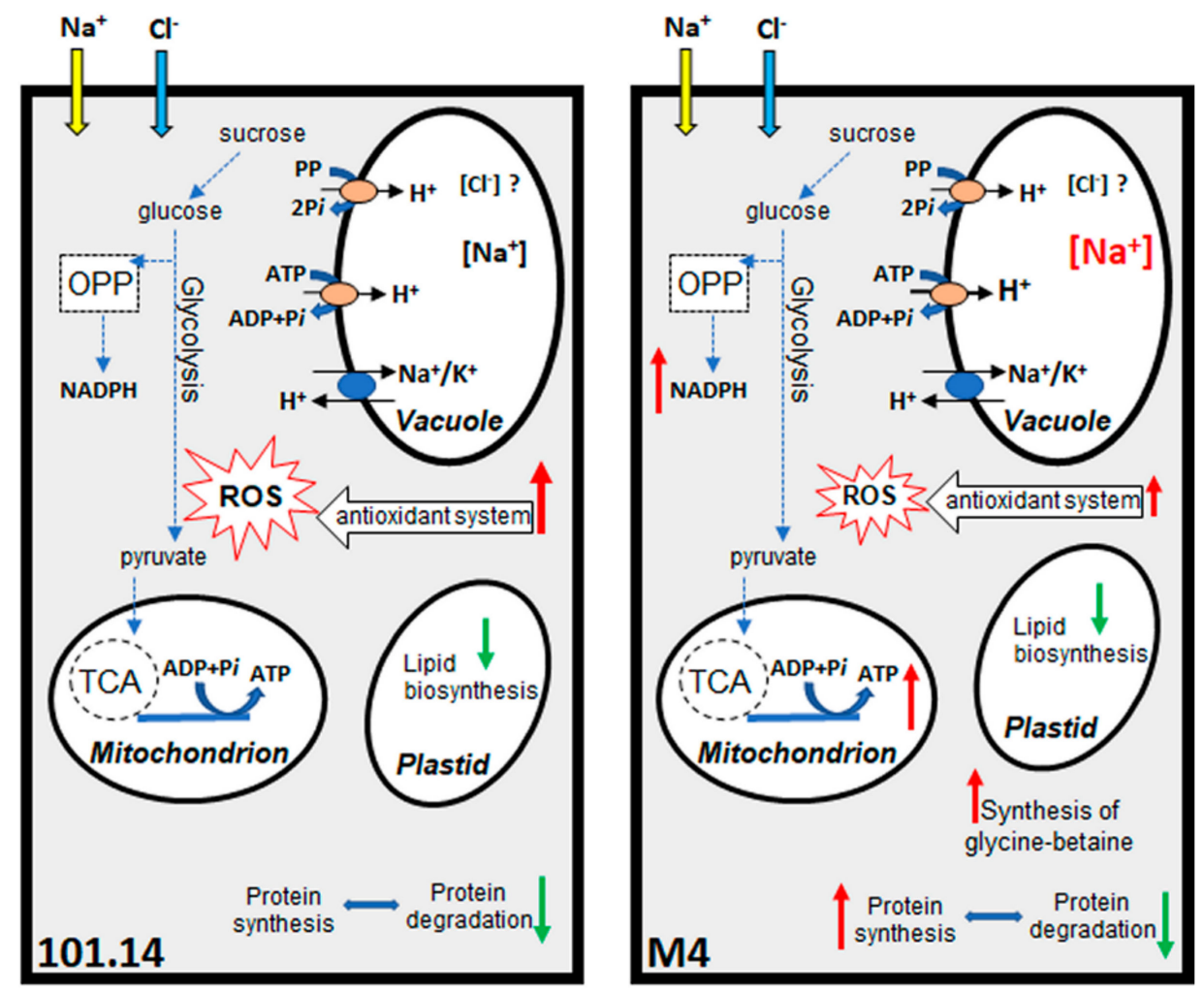

Figure 5. Schematic overview summarizing the main differences between 101.14 and M4 genotypes in biochemical processes highlighted by the proteomic analysis. Red arrows indicate an increase while green arrows indicate a decrease in the process. 


\section{Materials and Methods}

\subsection{Sample Material and Growth Conditions}

The 101.14 Millardet et de Grasset (V. riparia $\times$ V. rupestris $)$ and M4 [(V. vinifera $\times V$. berlandieri $) \times V$. berlandieri cv. Resseguier no. 1] grapevine rootstock genotypes were grown as previously described [17]. In detail, two-year-old plants were grown in 3-liter pots filled with sand-peat mixture (7:3 v/v). After a period of two weeks, to permit the acclimation of plants in the greenhouse conditions, an adequate number of uniform plants (i.e., similar height, number of sprouts and total leaf area) were selected for the experiment. The control plants were grown in a soil in which the field capacity was maintained at $80 \%$. Salt stress was induced by adding $5 \mathrm{mmol}$ of $\mathrm{NaCl}$ each day, to achieve a final $\mathrm{NaCl}$ concentration of ca. $120 \mathrm{mM}$, and maintaining the same soil field capacity of the control condition. After 21 days, the whole root system was sampled removing the soil by gentle shaking, rinsed twice with distilled water, blotted with paper towels, weighed and frozen in liquid $\mathrm{N}_{2}$. Samples were then grinded in liquid $\mathrm{N}_{2}$ to obtain a fine powder that was stored at $-80^{\circ} \mathrm{C}$. Aliquots of the samples were used for the different analyses. For each experimental condition, three biological samples, each derived from six randomly plants, were obtained.

\subsection{Chloride and Sodium Quantification}

Powder samples were suspended in three volumes of extraction solution $\left(0.2 \mathrm{mM} \mathrm{HNO}_{3}\right)$, boiled for $15 \mathrm{~min}$ and centrifuged at $10,000 \times \mathrm{g}$ for $10 \mathrm{~min}$. After centrifugation, the supernatants were collected (SN1), pellets were resuspended in $3 \mathrm{~mL}$ of distilled water and centrifuged at $10,000 \times g$ for 10 min to obtain SN2. The two supernatants were pooled (SN1 + SN2) and distilled water was added to a final volume of $10 \mathrm{~mL}$. The chloride content was then evaluated by QuantiChrom ${ }^{\mathrm{TM}}$ Chloride Assay Kit (BioAssay Systems, Hayward, CA, USA) following the manufacturer's instructions. Sodium concentration was measured by ICP-MS as previously described [17].

\subsection{Protein Extraction}

The total protein fraction was extracted from three biological replicates for each experimental condition as previously described [25,73] and dissolved in SDS-buffer (150 mM Tris-HCl, pH 6.8, 10\% $(w / w)$ glycerol, $2 \%(w / w)$ sodium dodecyl sulphate (SDS), $2 \%(v / v)$ 2-mercaptoethanol). After 5 min at $95^{\circ} \mathrm{C}$, samples were centrifuged at $10,000 \times g$ for $10 \mathrm{~min}$ and the supernatant was collected and stored at $-80{ }^{\circ} \mathrm{C}$. The protein concentration was determined by the 2-D Quant Kit (GE Healthcare Europe $\mathrm{GmbH}$, Freiburg, Germany).

\subsection{Western Blot Analyses}

Protein samples $(15 \mu \mathrm{g})$ were diluted with an equal volume of SDS-buffer added with $0.01 \%$ $(w / v)$ bromophenol blue, heated for $5 \mathrm{~min}$ at $90{ }^{\circ} \mathrm{C}$, separated by SDS-PAGE using $10.0 \%(w / v)$ acrylamide [74] and then electrophoretically transferred onto a polyvinylidene difluoride (PVDF) filter using the Trans-Blot Turbo System (Bio-Rad Laboratories, Hercules, CA, USA) in the presence of a buffer containing $25 \mathrm{mM}$ Tris, $192 \mathrm{mM}$ glycine $\mathrm{pH} 8.3$ and 20\% $(v / v)$ methanol. Filters were blocked for $1 \mathrm{~h}$ with TBS-T buffer ( $50 \mathrm{mM}$ Tris- $\mathrm{HCl}$ (pH 7.6), $200 \mathrm{mM} \mathrm{NaCl}$, and $0.1 \%(v / v)$ Tween 20) supplemented with $5 \%$ $(w / v)$ of albumin. After three washings of $5 \mathrm{~min}$ in TBS-T, filters were further blocked for $1 \mathrm{~h}$ with TBS-T supplemented with $5 \%(w / v)$ nonfat dried milk. After three washings ( 5 min each) in TBS-T, filters were incubated overnight at $4{ }^{\circ} \mathrm{C}$ with primary polyclonal antibodies raised against the $\mathrm{E}$ (i.e., $\varepsilon$ ) subunit of tonoplast $\mathrm{H}^{+}$-ATPase (1:2000 dilution, Agrisera, AS07 213), the $\mathrm{Na}^{+} / \mathrm{H}^{+}$antiporter, sodium/hydrogen exchanger (1:1000 dilution, Agrisera, AS09 484) and the vacuolar $\mathrm{H}^{+}$-pyrophosphatase (1:2000 dilution, Agrisera, AS12 1849). After washing with TBS-T, the filters were incubated for an additional $2 \mathrm{~h}$ at room temperature with a secondary antibody (alkaline phosphatase-conjugated anti-rabbit IgG, Sigma A3687). The blot was developed with nitroblue tetrazolium and 5-bromo-4-chloro-3-indolyl phosphate 
(FAST-BCIP/NBT, Sigma, B5655). Three technical replicates were performed, and quantification of the bands was conducted through densitometric analysis by using the software ImageJ (https://imagej.net/).

\subsection{Gel Electrophoresis, In-Gel Digestion and Mass Spectrometry Analysis}

Gel electrophoresis, in gel-digestion and mass spectrometry analyses were performed as previously described [26]. Briefly, $15 \mu \mathrm{g}$ of proteins were purified by partial 1D SDS-PAGE on $16 \%(w / v)$ polyacrylamide gel, accordingly to Leammli procedure [74] at $60 \mathrm{mV}$ for $30 \mathrm{~min}$. After Coomassie Brilliant Blue staining, gel bands were subjected to tryptic digestion [75], with the refinements described in [26].

All mass spectrometry experiments were conducted with an Agilent 6520 Q-TOF mass spectrometer equipped with an HPLC Chip Cube (Agilent Technologies, Cernusco sul Naviglio, Italy), as previously described [26]. In detail, chromatography was performed in a Polaris-HR-Chip-3C18 (Agilent Technologies), consisting of a 360-nL trap column and a $75 \mu \mathrm{m} \times 150-\mathrm{mm}$ analytical column (Polaris C18-A, $180 \AA, 3 \mu \mathrm{m}$ ), applying a 100-min non-linear gradient of acetonitrile from $5 \%$ to $50 \%$ $(v / v)$ at $0.4 \mu \mathrm{L} \mathrm{min}^{-1}$. Acquisition and analysis of the MS/MS spectra were performed with the following adaptations. The search was conducted against the Vitis (ID 3603) protein database downloaded from UniProtKB/Swiss-Prot (http://www.uniprot.org/) and concatenated with the reverse one. The threshold used for protein identification was peptide false discovery rate (FDR) $\leq 1 \%$ and number of unique peptides per protein $\geq 2$. Peptide quantification was obtained as the spectrum intensity (SI) of the precursor $\left(\mathrm{MH}^{+}\right)$. Protein quantification was obtained by summing the SI of all the identified peptides in the protein. Protein abundance was normalized as the percentage with respect to the abundance of all validated proteins in the sample [\%(SI)]. Two technical replicates were performed for each biological sample $(n=3)$. Proteins showing a fold-change of at least 1.4 between the two conditions (salt stress versus control) and for which the change was significant according to the Student's t-test $(p<0.05)$ were considered as significantly changed in abundance. The identified proteins were classified into metabolic functional classes according to the MapMan BIN ontology. The schematic metabolic pathways were obtained by MapMan software as previously described [25].

Supplementary Materials: Supplementary Materials can be found at http://www.mdpi.com/1422-0067/21/3/1076/s1.

Author Contributions: B.P. and L.E. contributed to the experimental work. Conceptualization, B.P. and L.E.; formal analysis, B.P. and L.E.; funding acquisition, A.S., O.F., L.E.; investigation, B.P. and L.E.; supervision, L.E.; writing-original draft, L.E.; writing-review and editing, B.P., A.S., O.F. and L.E. All authors have read and agreed to the published version of the manuscript.

Funding: This work was supported by “AGER- SERRES Project”, grant n 2010-2105.

Acknowledgments: The authors thank Živa Ramšak (Department of Biotechnology and Systems Biology, National Institute of Biology, 1000 Ljubljana, Slovenia), member of GoMapMan staff, http://www.gomapman.org/, for providing mapping file of Vitis vinifera. The authors thank Silvia Morgutti (University of Milan) for polishing the English in the manuscript.

Conflicts of Interest: The authors declare no conflicts of interest.

\section{References}

1. Munns, R. Chapter 1-Plant Adaptations to Salt and Water Stress: Differences and Commonalities. In Advances in Botanical Research; Turkan, I., Ed.; Plant Responses to Drought and Salinity Stress; Academic Press: Waltham, MA, USA, 2011; Volume 57, pp. 1-32. [CrossRef]

2. Munns, R.; Tester, M. Mechanisms of Salinity Tolerance. Annu. Rev. Plant Biol. 2008, 59, 651-681. [CrossRef] [PubMed]

3. Hasegawa, P.M.; Bressan, R.A.; Zhu, J.-K.; Bohnert, H.J. Plant Cellular and Molecular Responses to High Salinity. Annu. Rev. Plant. Physiol. Plant. Mol. Biol. 2000, 51, 463-499. [CrossRef] [PubMed]

4. Isayenkov, S.V.; Maathuis, F.J.M. Plant Salinity Stress: Many Unanswered Questions Remain. Front. Plant Sci. 2019, 10. [CrossRef] [PubMed] 
5. Deinlein, U.; Stephan, A.B.; Horie, T.; Luo, W.; Xu, G.; Schroeder, J.I. Plant Salt-Tolerance Mechanisms. Trends Plant Sci. 2014, 19, 371-379. [CrossRef]

6. Walker, R.R.; Blackmore, D.H.; Clingeleffer, P.R.; Iacono, F. Effect of Salinity and Ramsey Rootstock on Ion Concentrations and Carbon Dioxide Assimilation in Leaves of Drip-Irrigated, Field-Grown Grapevines (Vitis vinifera L. Cv. Sultana). Aust. J. Grape Wine Res. 1997, 3, 66-74. [CrossRef]

7. Walker, R.R.; Blackmore, D.H.; Clingeleffer, P.R. Impact of Rootstock on Yield and Ion Concentrations in Petioles, Juice and Wine of Shiraz and Chardonnay in Different Viticultural Environments with Different Irrigation Water Salinity. Aust. J. Grape Wine Res. 2010, 16, 243-257. [CrossRef]

8. Tregeagle, J.M.; Tisdall, J.M.; Tester, M.; Walker, R.R. Cl-Uptake, Transport and Accumulation in Grapevine Rootstocks of Differing Capacity for Cl-Exclusion. Funct. Plant Biol. 2010, 37, 665-673. [CrossRef]

9. Gong, H.; Blackmore, D.H.; Walker, R.R. Organic and Inorganic Anions in Shiraz and Chardonnay Grape Berries and Wine as Affected by Rootstock under Saline Conditions. Aust. J. Grape Wine Res. 2010, 16, 227-236. [CrossRef]

10. Henderson, S.W.; Baumann, U.; Blackmore, D.H.; Walker, A.R.; Walker, R.R.; Gilliham, M. Shoot Chloride Exclusion and Salt Tolerance in Grapevine Is Associated with Differential Ion Transporter Expression in Roots. BMC Plant Biol. 2014, 14, 273. [CrossRef]

11. Walker, R.R.; Blackmore, D.H.; Clingeleffer, P.R.; Emanuelli, D. Rootstock Type Determines Tolerance of Chardonnay and Shiraz to Long-Term Saline Irrigation. Aust. J. Grape Wine Res. 2014, 20, 496-506. [CrossRef]

12. Ollat, N.; Peccoux, A.; Papura, D.; Esmenjaud, D.; Marguerit, E.; Tandonnet, J.-P.; Bordenave, L.; Cookson, S.J.; Barrieu, F.; Rossdeutsch, L.; et al. Rootstocks as a Component of Adaptation to Environment. In Grapevine in a Changing Environment; John Wiley \& Sons, Ltd.: West Sussex, UK, 2016; pp. 68-108. [CrossRef]

13. Gong, H.; Blackmore, D.; Clingeleffer, P.; Sykes, S.; Jha, D.; Tester, M.; Walker, R. Contrast in Chloride Exclusion between Two Grapevine Genotypes and Its Variation in Their Hybrid Progeny. J. Exp. Bot. 2011, 62, 989-999. [CrossRef] [PubMed]

14. Conde, A.; Breia, R.; Moutinho-Pereira, J.; Grimplet, J.; Gerós, H. Metabolic Rearrangements in Grapevine Response to Salt Stress. In Grapevine in a Changing Environment; John Wiley \& Sons, Ltd.: West Sussex, UK, 2016; pp. 279-298. [CrossRef]

15. Mirás-Avalos, J.M.; Intrigliolo, D.S. Grape Composition under Abiotic Constrains: Water Stress and Salinity. Front. Plant Sci. 2017, 8. [CrossRef] [PubMed]

16. Henderson, S.W.; Dunlevy, J.D.; Wu, Y.; Blackmore, D.H.; Walker, R.R.; Edwards, E.J.; Gilliham, M.; Walker, A.R. Functional Differences in Transport Properties of Natural HKT1;1 Variants Influence Shoot Na+ Exclusion in Grapevine Rootstocks. New Phytol. 2018, 217, 1113-1127. [CrossRef] [PubMed]

17. Meggio, F.; Prinsi, B.; Negri, A.S.; Lorenzo, G.S.D.; Lucchini, G.; Pitacco, A.; Failla, O.; Scienza, A.; Cocucci, M.; Espen, L. Biochemical and Physiological Responses of Two Grapevine Rootstock Genotypes to Drought and Salt Treatments. Aust. J. Grape Wine Res. 2014, 20, 310-323. [CrossRef]

18. Shavrukov, Y. Salt Stress or Salt Shock: Which Genes Are We Studying? J. Exp. Bot. 2013, 64, 119-127. [CrossRef]

19. Assaha, D.V.M.; Ueda, A.; Saneoka, H.; Al-Yahyai, R.; Yaish, M.W. The Role of Na+ and K+ Transporters in Salt Stress Adaptation in Glycophytes. Front. Physiol. 2017, 8. [CrossRef]

20. Hamaji, K.; Nagira, M.; Yoshida, K.; Ohnishi, M.; Oda, Y.; Uemura, T.; Goh, T.; Sato, M.H.; Morita, M.T.; Tasaka, M.; et al. Dynamic Aspects of Ion Accumulation by Vesicle Traffic under Salt Stress in Arabidopsis. Plant Cell Physiol. 2009, 50, 2023-2033. [CrossRef]

21. Undurraga, S.F.; Santos, M.P.; Paez-Valencia, J.; Yang, H.; Hepler, P.K.; Facanha, A.R.; Hirschi, K.D.; Gaxiola, R.A. Arabidopsis Sodium Dependent and Independent Phenotypes Triggered by H+-PPase up-Regulation Are SOS1 Dependent. Plant Sci. 2012, 183, 96-105. [CrossRef]

22. Dietz, K.J.; Tavakoli, N.; Kluge, C.; Mimura, T.; Sharma, S.S.; Harris, G.C.; Chardonnens, A.N.; Golldack, D. Significance of the V-type ATPase for the Adaptation to Stressful Growth Conditions and Its Regulation on the Molecular and Biochemical Level. J. Exp. Bot. 2001, 52, 1969-1980. [CrossRef]

23. Zhang, M.; Fang, Y.; Liang, Z.; Huang, L. Enhanced Expression of Vacuolar H+-ATPase Subunit E in the Roots Is Associated with the Adaptation of Broussonetia papyrifera to Salt Stress. PLoS ONE 2012, 7, e48183. [CrossRef]

24. Gilmore, J.M.; Washburn, M.P. Advances in Shotgun Proteomics and the Analysis of Membrane Proteomes. J. Proteom. 2010, 73, 2078-2091. [CrossRef] [PubMed] 
25. Prinsi, B.; Negri, A.S.; Failla, O.; Scienza, A.; Espen, L. Root Proteomic and Metabolic Analyses Reveal Specific Responses to Drought Stress in Differently Tolerant Grapevine Rootstocks. BMC Plant Biol. 2018, 18, 126. [CrossRef] [PubMed]

26. Prinsi, B.; Espen, L. Time-Course of Metabolic and Proteomic Responses to Different Nitrate/Ammonium Availabilities in Roots and Leaves of Maize. Int. J. Mol. Sci. 2018, 19, 2202. [CrossRef] [PubMed]

27. Thimm, O.; Bläsing, O.; Gibon, Y.; Nagel, A.; Meyer, S.; Krüger, P.; Selbig, J.; Müller, L.A.; Rhee, S.Y.; Stitt, M. Mapman: A User-Driven Tool to Display Genomics Data Sets onto Diagrams of Metabolic Pathways and Other Biological Processes. Plant J. 2004, 37, 914-939. [CrossRef] [PubMed]

28. Jiang, Y.; Yang, B.; Harris, N.S.; Deyholos, M.K. Comparative Proteomic Analysis of NaCl Stress-Responsive Proteins in Arabidopsis Roots. J. Exp. Bot. 2007, 58, 3591-3607. [CrossRef]

29. Zhang, H.; Han, B.; Wang, T.; Chen, S.; Li, H.; Zhang, Y.; Dai, S. Mechanisms of Plant Salt Response: Insights from Proteomics. J. Proteome Res. 2012, 11, 49-67. [CrossRef]

30. Kruger, N.J.; Dennis, D.T. Molecular Properties of Pyrophosphate: Fructose-6-Phosphate Phosphotransferase from Potato Tuber. Arch. Biochem. Biophys. 1987, 256, 273-279. [CrossRef]

31. Wong, J.H.; Kiss, F.; Wu, M.-X.; Buchanan, B.B. Pyrophosphate Fructose-6-P 1-Phosphotransferase from Tomato Fruit: Evidence for Change during Ripening. Plant Physiol. 1990, 94, 499-506. [CrossRef]

32. Ghosh, D.; Xu, J. Abiotic Stress Responses in Plant Roots: A Proteomics Perspective. Front. Plant Sci. $2014,5$. [CrossRef]

33. Munns, R.; Day, D.A.; Fricke, W.; Watt, M.; Arsova, B.; Barkla, B.J.; Bose, J.; Byrt, C.S.; Chen, Z.-H.; Foster, K.J.; et al. Energy Costs of Salt Tolerance in Crop Plants. New Phytol. 2019. [CrossRef]

34. Zorrilla-Fontanesi, Y.; Rouard, M.; Cenci, A.; Kissel, E.; Do, H.; Dubois, E.; Nidelet, S.; Roux, N.; Swennen, R.; Carpentier, S.C. Differential Root Transcriptomics in a Polyploid Non-Model Crop: The Importance of Respiration during Osmotic Stress. Sci. Rep. 2016, 6, 1-15. [CrossRef]

35. Stein, O.; Granot, D. An Overview of Sucrose Synthases in Plants. Front. Plant Sci. 2019, 10. [CrossRef] [PubMed]

36. Corpas, F.J.; Barroso, J.B. NADPH-Generating Dehydrogenases: Their Role in the Mechanism of Protection against Nitro-Oxidative Stress Induced by Adverse Environmental Conditions. Front. Environ. Sci. 2014, 2. [CrossRef]

37. Chen, Q.; Wang, B.; Ding, H.; Zhang, J.; Li, S. Review: The Role of NADP-Malic Enzyme in Plants under Stress. Plant Sci. 2019, 281, 206-212. [CrossRef] [PubMed]

38. Nemoto, Y.; Kawakami, N.; Sasakuma, T. Isolation of Novel Early Salt-Responding Genes from Wheat (Triticum aestivum L.) by Differential Display. Theor. Appl. Genet. 1999, 98, 673-678. [CrossRef]

39. Nemoto, Y.; Sasakuma, T. Specific Expression of Glucose-6-Phosphate Dehydrogenase (G6PDH) Gene by Salt Stress in Wheat (Triticum aestivum L.). Plant Sci. 2000, 158, 53-60. [CrossRef]

40. Cardi, M.; Castiglia, D.; Ferrara, M.; Guerriero, G.; Chiurazzi, M.; Esposito, S. The Effects of Salt Stress Cause a Diversion of Basal Metabolism in Barley Roots: Possible Different Roles for Glucose-6-Phosphate Dehydrogenase Isoforms. Plant Physiol. Biochem. 2015, 86, 44-54. [CrossRef]

41. Singh, M.; Kumar, J.; Singh, S.; Singh, V.P.; Prasad, S.M. Roles of Osmoprotectants in Improving Salinity and Drought Tolerance in Plants: A Review. Rev. Environ. Sci. Biotechnol. 2015, 14, 407-426. [CrossRef]

42. Hong, Y.; Zhang, W.; Wang, X. Phospholipase D and Phosphatidic Acid Signalling in Plant Response to Drought and Salinity. Plant Cell Environ. 2010, 33, 627-635. [CrossRef]

43. Hou, Q.; Ufer, G.; Bartels, D. Lipid Signalling in Plant Responses to Abiotic Stress. Plant Cell Environ. 2016, 39, 1029-1048. [CrossRef]

44. Troncoso-Ponce, M.A.; Nikovics, K.; Marchive, C.; Lepiniec, L.; Baud, S. New Insights on the Organization and Regulation of the Fatty Acid Biosynthetic Network in the Model Higher Plant Arabidopsis thaliana. Biochimie 2016, 120, 3-8. [CrossRef] [PubMed]

45. Joyard, J.; Ferro, M.; Masselon, C.; Seigneurin-Berny, D.; Salvi, D.; Garin, J.; Rolland, N. Chloroplast Proteomics Highlights the Subcellular Compartmentation of Lipid Metabolism. Prog. Lipid Res. 2010, 49, 128-158. [CrossRef] [PubMed]

46. Mou, Z.; He, Y.; Dai, Y.; Liu, X.; Li, J. Deficiency in Fatty Acid Synthase Leads to Premature Cell Death and Dramatic Alterations in Plant Morphology. Plant Cell 2000, 12, 405-417. [CrossRef] [PubMed]

47. Hildebrandt, T.M.; Nunes Nesi, A.; Araújo, W.L.; Braun, H.-P. Amino Acid Catabolism in Plants. Mol. Plant 2015, 8, 1563-1579. [CrossRef] 
48. Batista-Silva, W.; Heinemann, B.; Rugen, N.; Nunes-Nesi, A.; Araújo, W.L.; Braun, H.-P.; Hildebrandt, T.M. The Role of Amino Acid Metabolism during Abiotic Stress Release. Plant Cell Environ. 2019, 42, 1630-1644. [CrossRef] [PubMed]

49. Ding, L.; Hofius, D.; Hajirezaei, M.-R.; Fernie, A.R.; Börnke, F.; Sonnewald, U. Functional Analysis of the Essential Bifunctional Tobacco Enzyme 3-Dehydroquinate Dehydratase/Shikimate Dehydrogenase in Transgenic Tobacco Plants. J. Exp. Bot. 2007, 58, 2053-2067. [CrossRef]

50. Tolbert, N.E.; Yamazaki, R.K.; Oeser, A. Localization and Properties of Hydroxypyruvate and Glyoxylate Reductases in Spinach Leaf Particles. J. Biol. Chem. 1970, 245, 5129-5136.

51. Bernard, S.M.; Habash, D.Z. The Importance of Cytosolic Glutamine Synthetase in Nitrogen Assimilation and Recycling. New Phytol. 2009, 182, 608-620. [CrossRef]

52. Prinsi, B.; Espen, L. Mineral Nitrogen Sources Differently Affect Root Glutamine Synthetase Isoforms and Amino Acid Balance among Organs in Maize. BMC Plant Biol. 2015, 15, 96. [CrossRef]

53. Moreno, J.I.; Martín, R.; Castresana, C. Arabidopsis SHMT1, a Serine Hydroxymethyltransferase That Functions in the Photorespiratory Pathway Influences Resistance to Biotic and Abiotic Stress. Plant J. 2005, 41, 451-463. [CrossRef]

54. Terol, J.; Bargues, M.; Carrasco, P.; Pérez-Alonso, M.; Paricio, N. Molecular Characterization and Evolution of the Protein Phosphatase 2A B' Regulatory Subunit Family in Plants. Plant Physiol. 2002, 129, 808-822. [CrossRef] [PubMed]

55. Máthé, C.; Garda, T.; Freytag, C. The Role of Serine-Threonine Protein Phosphatase PP2A in Plant Oxidative Stress Signaling-Facts and Hypotheses. Int. J. Mol. Sci. 2019, 20, 3028. [CrossRef] [PubMed]

56. Machingura, M.; Salomon, E.; Jez, J.M.; Ebbs, S.D. The $\beta$-Cyanoalanine Synthase Pathway: Beyond Cyanide Detoxification. Plant Cell Environ. 2016, 39, 2329-2341. [CrossRef] [PubMed]

57. Liang, W.-S. Drought Stress Increases Both Cyanogenesis and $\beta$-Cyanoalanine Synthase Activity in Tobacco. Plant Sci. 2003, 165, 1109-1115. [CrossRef]

58. Machingura, M.; Sidibe, A.; Wood, A.J.; Ebbs, S.D. The $\beta$-Cyanoalanine Pathway Is Involved in the Response to Water Deficit in Arabidopsis thaliana. Plant Physiol. Biochem. 2013, 63, 159-169. [CrossRef]

59. Prinsi, B.; Negri, A.S.; Fedeli, C.; Morgutti, S.; Negrini, N.; Cocucci, M.; Espen, L. Peach Fruit Ripening: A Proteomic Comparative Analysis of the Mesocarp of Two Cultivars with Different Flesh Firmness at Two Ripening Stages. Phytochemistry 2011, 72, 1251-1262. [CrossRef]

60. Lorenz, W.W.; Sun, F.; Liang, C.; Kolychev, D.; Wang, H.; Zhao, X.; Cordonnier-Pratt, M.-M.; Pratt, L.H.; Dean, J.F.D. Water Stress-Responsive Genes in Loblolly Pine (Pinus taeda) Roots Identified by Analyses of Expressed Sequence Tag Libraries. Tree Physiol. 2006, 26, 1-16. [CrossRef]

61. Gregorová, Z.; Kováčik, J.; Klejdus, B.; Maglovski, M.; Kuna, R.; Hauptvogel, P.; Matušíková, I. Drought-Induced Responses of Physiology, Metabolites, and PR Proteins in Triticum aestivum. J. Agric. Food Chem. 2015, 63, 8125-8133. [CrossRef]

62. Davidson, R.M.; Reeves, P.A.; Manosalva, P.M.; Leach, J.E. Germins: A Diverse Protein Family Important for Crop Improvement. Plant Sci. 2009, 177, 499-510. [CrossRef]

63. Lu, M.; Han, Y.-P.; Gao, J.-G.; Wang, X.-J.; Li, W.-B. Identification and Analysis of the Germin-like Gene Family in Soybean. BMC Genom. 2010, 11, 620. [CrossRef]

64. Chen, J.-Y.; Dai, X.-F. Cloning and Characterization of the Gossypium hirsutum Major Latex Protein Gene and Functional Analysis in Arabidopsis thaliana. Planta 2010, 231, 861-873. [CrossRef]

65. Demidchik, V. Mechanisms of Oxidative Stress in Plants: From Classical Chemistry to Cell Biology. Environ. Exp. Bot. 2015, 109, 212-228. [CrossRef]

66. Choudhury, F.K.; Rivero, R.M.; Blumwald, E.; Mittler, R. Reactive Oxygen Species, Abiotic Stress and Stress Combination. Plant J. 2017, 90, 856-867. [CrossRef]

67. Mittler, R.; Vanderauwera, S.; Gollery, M.; Van Breusegem, F. Reactive Oxygen Gene Network of Plants. Trends Plant Sci. 2004, 9, 490-498. [CrossRef]

68. Csiszár, J.; Horváth, E.; Váry, Z.; Gallé, Á.; Bela, K.; Brunner, S.; Tari, I. Glutathione Transferase Supergene Family in Tomato: Salt Stress-Regulated Expression of Representative Genes from Distinct GST Classes in Plants Primed with Salicylic Acid. Plant Physiol. Biochem. 2014, 78, 15-26. [CrossRef]

69. Cruz-Rus, E.; Botella, M.A.; Valpuesta, V.; Gomez-Jimenez, M.C. Analysis of Genes Involved in L-Ascorbic Acid Biosynthesis during Growth and Ripening of Grape Berries. J. Plant Physiol. 2010, 167, 739-748. [CrossRef] 
70. Tao, J.; Wu, H.; Li, Z.; Huang, C.; Xu, X. Molecular Evolution of GDP-D-Mannose Epimerase (GME), a Key Gene in Plant Ascorbic Acid Biosynthesis. Front. Plant Sci. 2018, 9. [CrossRef]

71. Xu, J.; Xing, X.-J.; Tian, Y.-S.; Peng, R.-H.; Xue, Y.; Zhao, W.; Yao, Q.-H. Transgenic Arabidopsis Plants Expressing Tomato Glutathione S-Transferase Showed Enhanced Resistance to Salt and Drought Stress. PLoS ONE 2015, 10, e0136960. [CrossRef]

72. Peng, X.; Yu, D.; Yan, J.; Zhang, N.; Lin, J.; Wang, J. Physiological and Proteomic Analyses Reveal Adaptive Mechanisms of Ryegrass (Annual vs. Perennial) Seedlings to Salt Stress. Agronomy 2019, 9, 843. [CrossRef]

73. Prinsi, B.; Negri, A.S.; Quattrocchio, F.M.; Koes, R.E.; Espen, L. Proteomics of Red and White Corolla Limbs in Petunia Reveals a Novel Function of the Anthocyanin Regulator ANTHOCYANIN1 in Determining Flower Longevity. J. Proteom. 2016, 131, 38-47. [CrossRef]

74. Laemmli, U.K. Cleavage of Structural Proteins during the Assembly of the Head of Bacteriophage T4. Nature 1970, 227, 680-685. [CrossRef] [PubMed]

75. Prinsi, B.; Negri, A.S.; Pesaresi, P.; Cocucci, M.; Espen, L. Evaluation of Protein Pattern Changes in Roots and Leaves of Zea Mays plants in Response to Nitrate Availability by Two-Dimensional Gel Electrophoresis Analysis. BMC Plant Biol. 2009, 9, 113. [CrossRef] [PubMed]

(C) 2020 by the authors. Licensee MDPI, Basel, Switzerland. This article is an open access article distributed under the terms and conditions of the Creative Commons Attribution (CC BY) license (http://creativecommons.org/licenses/by/4.0/). 